\title{
Sublittoral hard substrate communities off Helgoland
}

\author{
M. J. de Kluijver \\ Institute of Taxonomic Zoology, University of Amsterdam; \\ P.O. Box 4766, NL-1009 AT Amsterdam, The Netherlands \\ and \\ SBNO: P.O. Box 16915, NL-1001 RK Amsterdam, The Netherlands
}

\begin{abstract}
In the Helgoland region eight sublittoral hard substrate communities occur. These communities were stationary in time during the years 1987-1989. The major governing parameters are the available amount of daylight and the degree of exposure to water movement. In the photic zone, three communities are met with, one of which is widespread and appears to be independent of the exposure to water movement. Under exposed conditions, at the lower border of the photic zone, a second community is observed. A third community is established on erosive muschelkalk substrates. In the aphotic zone also, three communities are found. The distribution of these communities is related to the rate of water movement. One community is divided into three variants, with different preferences regarding the angle of inclination and nature of the substrates. In the artificially constructed harbours, where sedimentation exceeds erosion, two different communities have settled. In the community under moderately sheltered conditions many species are found which also occur in the natural photic zone. Under extremely sheltered conditions a group of species has become dominant which is very rare in the Helgoland region outside the quay-walls but which has been described as being characteristic for sheltered localities elsewhere.
\end{abstract}

\section{INTRODUCTION}

Although many investigations have been performed in the Helgoland region, the sublittoral communities on hard substrates have been largely neglected until now. Recent investigations on rocky eulittoral communities were carried out by Markham \& Munda (1980), Munda \& Markham (1982) and Janke (1986). Sublittoral studies were started by Caspers, who made inventories of the fauna of the "Tiefe Rinne" (Caspers, 1938), oysterbanks (Caspers, 1950), and buoys (Caspers, 1952). Investigations on the development of sublittoral communities were carried out by Anger (1978) and Harms \& Anger (1983). Sublittoral algae were studied by Lüning (1970) and Kornmann \& Sahling (1977).

Sublittoral benthic communities are subjected to stable environmental parameters and are thus assumed to have a predictable specific composition. This would make them particularly useful for the detection of short-term disturbances in the marine ecosystem. In order to use benthic communities for ecological monitoring, a reproducible description of both the communities and the environmental parameters must be available. Reproducibility makes demands upon the methods of investigation. In the first place, communities must be studied as a whole. Many of the publications on marine hard substrate communities deal with only one particular taxonomic group, for example algae (Lüning, 1970) or Polychaeta (Klöckner, 1976; Gillandt, 1979a, 1979b). Secondly, the data must be 
quantified as much as possible. Studies on sublittoral hard substrate communities as a whole are often qualitative (Hiscock \& Hiscock, 1980; Könnecker \& Keegan, 1983). The main benefit of quantitative studies is the description of communities by means of characteristic species (common species, but restricted to just one community) and dominant species (occurring in more communities, but abundant in just a few communities). Examples of such quantitative studies on marine hard substrate communities are: Gislen (1930), Van Soest \& Weinberg (1981), Kaandorp (1986), De Kluijver (1989) and De Kluijver et al. (in prep.).

Helgoland is situated in the German Bight some $50 \mathrm{~km}$ from the nearest mainland (Eiderstedt). Because of its isolated position, the marine environment around Helgoland displays an offshore character. For the major part of the year it is under the influence of the North Sea water body (Martens, 1978), which guarantees a relatively constant environment. Despite the inflow of fresh water with diluted pollutants into the southern North Sea and the eastern German Bight from the rivers Westerschelde, Maas, Rhine, Elbe and Weser (Korringa, 1968; De Ruijter et al., 1987), the area around Helgoland must be considered relatively unpolluted compared to more inshore localities in the southern North Sea.

\section{MATERIALS AND METHODS}

\section{Sampling}

Hard substrate biota were sampled at 80 stations, distributed over 14 localities (Fig. 1). In Table 1, the characteristics of the stations are shown. The depth of a station is given relative to Mean Sea Level (between high and low tide). In general, the biota are composed of different structural layers. In the studied area, a distinguishable top layer (TL) of thalli of brown algae of the genus Laminaria may be developed. A middle layer (ML) is formed by organisms growing erect from the substrate, but which do not belong to the top layer. This layer also contains the epiphytic, epizoic and endozoic organisms. The encrusting layer (EL) consists of organisms adhering to the substrate.

In each different structural layer, the percentage cover of the vertical projection of all sessile organisms was estimated, using a quadrat of $50 \times 50 \mathrm{~cm}$. Vagile organisms were scored qualitatively at all stations, but were not used for cluster analysis.

\section{Minimal sampling area}

In order to obtain a representative sample, 3 to 4 quadrats of $50 \times 50 \mathrm{~cm}$ were sampled at each station. The minimal sampling area required was determined for station 2 (West Seite $-9.9 \mathrm{~m}$ ), by sampling 10 quadrats of $32 \times 32 \mathrm{~cm}$. Data were processed using the program MINAR (Kaandorp, 1986) with logarithmically transformed data. The algorithm and transformation used in this process were the same as those used during cluster analysis. Similarity was plotted as a function of the sampled surface (Fig. 2). Weinberg (1978) suggested a similarity level of 0.70 at which the minimal area is obtained. This level is reached within 2 quadrats $\left(20.5 \mathrm{dm}^{2}\right)$.

The size of the used quadrats does not influence the minimal sampling area. Figure 3 shows a computer simulation for reaching these minimal sampling areas for different quadrat sizes both in a homogeneously and a patchily distributed community. Although 


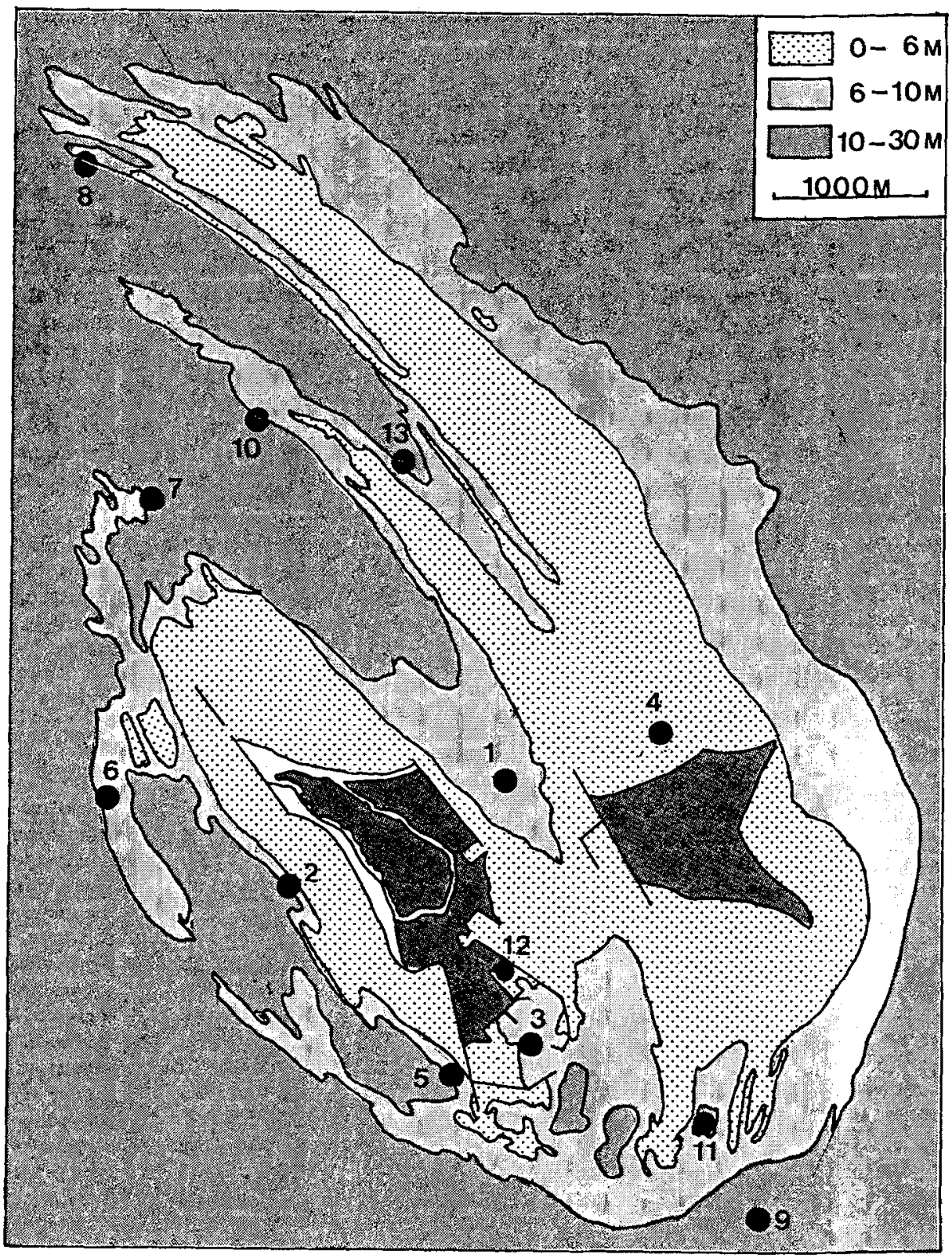

Fig. 1. Map of Helgoland showing the localities (after Lüning, 1970). 1: Nordreede (West/Ost); 2: West Seite; 3: Vorhafen; 4: Düne (Kalberdans/Wittkliffbrunn); 5: Kringel; 6: Nordmole; 7: Repulsegrund; 8: Sellebrunnknoll; 9: Düne-Süd; 10: Nordhafenknoll; 11: Hamburger Loch; 12: Südhafen; 13: Skittgatt; 14 : Steingrund $\left(54^{\circ} 14^{\prime} N, 08^{\circ} 03^{\prime} \mathrm{E}\right.$ ) (not on the map) 
Table 1. Description of the stations sampled, sequence according to the dendrogram (cf. Figure 4)

\begin{tabular}{|c|c|c|c|c|c|c|c|}
\hline Station & Location & $\begin{array}{c}\text { Depth } \\
\text { (m) }\end{array}$ & Date. & Slope & Orient & $\begin{array}{c}\text { Area } \\
\left(\mathrm{dm}^{2}\right)\end{array}$ & Substrate \\
\hline \multicolumn{8}{|c|}{ Community A } \\
\hline 01 & Nordreede-West & 6.5 & $03-07-87$ & 10 & 90 & 100 & sandstone \\
\hline 09 & Nordreede-West & 6.1 & $21-07-87$ & 15 & 50 & 100 & sandstone \\
\hline 37 & Nordreede-West & 5.7 & $05-07-88$ & 15 & 90 & 75 & sandstone \\
\hline 05 & Düne-Kalberdans & 4.8 & $13-07-87$ & 10 & 110 & 100 & limestone \\
\hline 72 & Nordreede-West & 4.5 & $15-06-89$ & 20 & 60 & 75 & sandstone \\
\hline 03 & West Seite & 5.9 & $07-07-87$ & 25 & 30 & 100 & sandstone \\
\hline 07 & Kringel & 4.7 & $20-07-87$ & 25 & 220 & 100 & sandstone \\
\hline 30 & Nordreede-West & 6.1 & $10-09-87$ & 15 & 340 & 75 & sandstone \\
\hline 76 & West Seite & 4.6 & $21-06-89$ & 30 & 90 & 75 & sandstone \\
\hline 63 & Nordhafenknoll & 6.5 & $07-06-89$ & 10 & 240 & 75 & limestone \\
\hline 65 & Skittgatt & 10.8 & $08-06-89$ & 20 & 60 & 75 & limestone \\
\hline 20 & Nordmole & 8.7 & $01-09-87$ & 5 & 280 & 75 & limestone \\
\hline 28 & Kringel & 5.4 & $09-09-87$ & 25 & 270 & 75 & concrete \\
\hline \multicolumn{8}{|c|}{ Community B } \\
\hline 06 & Kringel & 9.2 & $14-07-87$ & 25 & 180 & 100 & sandstone \\
\hline 10 & Kringel & 10.0 & $21-07-87$ & 35 & 20 & 100 & limestone \\
\hline 14 & Kringel & 9.2 & $24-07-87$ & 70 & 350 & 75 & sandstone \\
\hline 59 & Hamburger Loch & 9.7 & $27-07-88$ & 25 & 90 & 75 & limestone \\
\hline 34 & Kringel & 9.3 & $16-09-87$ & 10 & - & 75 & sandstone \\
\hline \multicolumn{8}{|c|}{ Community $\mathrm{C}$} \\
\hline 16 & Düne-Wittkliffbrunn & 2.1 & $27-07-87$ & 5 & 270 & 75 & muschelkalk \\
\hline 23 & Düne-Wittkliffbrunn & 3.7 & $03-09-87$ & 25 & 90 & 75 & muschelkalk \\
\hline \multicolumn{8}{|c|}{ Community D } \\
\hline 02 & West Seite & 9.9 & $06-07-87$ & 10 & 240 & 102 & sandstone \\
\hline 08 & Kringel & 11.0 & $20-07-87$ & 5 & 130 & 100 & sandstone \\
\hline 21 & Repulsegrund & 14.3 & $02-09-87$ & 10 & 0 & 100 & sandstone \\
\hline 31 & Repulsegrund & 12.7 & $14-09-87$ & 10 & - & 100 & sandstone \\
\hline 18 & West Seite & 13.2 & $30-07-87$ & 30 & 170 & 100 & limestone \\
\hline 17 & Nordmole & 11.6 & $29-07-87$ & 15 & 210 & 75 & sandstone \\
\hline 53 & West Seite & 11.3 & $21-07-88$ & 10 & 240 & 75 & limestone \\
\hline 42 & Repulsegrund & 10.0 & $08-07-88$ & 70 & 240 & 100 & limestone \\
\hline 43 & Sellebrunnknoll & 10.8 & $11-07-88$ & 80 & 240 & 100 & limestone \\
\hline 44 & Nordhafenknoll & 11.8 & $11-07-88$ & 5 & 150 & 100 & limestone \\
\hline 47 & Repulsegrund & 12.2 & $14-07-88$ & 10 & 300 & 75 & limestone \\
\hline 52 & Repulsegrund & 11.2 & $20-07-88$ & 10 & 270 & 75 & limestone \\
\hline 39 & West Seite & 13.5 & $06-07-88$ & 10 & 220 & 75 & limestone \\
\hline 41 & Repulsegrund & 14.1 & $07-07-88$ & 5 & - & 100 & sandstone \\
\hline 51 & Repulsegrund & 12.6 & $20-07-88$ & 10 & 270 & 75 & sandstone \\
\hline 58 & Nordhafenknoll & 12.7 & $27-07-88$ & 5 & - & 75 & sandstone \\
\hline 49 & Hamburger Loch & 11.6 & $15-07-88$ & 10 & 90 & 100 & limestone \\
\hline 73 & Repulsegrund & 13.9 & $19-06-89$ & 0 & - & 75 & sandstone \\
\hline 61 & Kringel & 14.2 & $05-06-89$ & 0 & - & 75 & sandstone \\
\hline 54 & West Seite & 12.8 & $21-07-88$ & 10 & 240 & 75 & sandstone \\
\hline 12 & West Seite & 17.3 & $22-07-87$ & 5 & 220 & 100 & sandstone \\
\hline 69 & West Seite & 14.7 & $13-06-89$ & 0 & - & 75 & sandstone \\
\hline 78 & Sellebrunnknoll & 16.6 & $23-06-89$ & 0 & - & 75 & sandstone \\
\hline 19 & West Seite & 15.3 & $31-08-87$ & 5 & 210 & 75 & sandstone \\
\hline
\end{tabular}


Table 1 (continued)

\begin{tabular}{|c|c|c|c|c|c|c|c|}
\hline Station & Location & $\begin{array}{c}\text { Depth } \\
\text { (m) }\end{array}$ & Date & Slope & Orient & $\begin{array}{l}\text { Area } \\
\left(\mathrm{dm}^{2}\right)\end{array}$ & Substrate \\
\hline \multicolumn{8}{|c|}{ Community D } \\
\hline 35 & Nordhafenknoll & 14.2 & $17-09-87$ & 10 & - & 75 & sandstone \\
\hline 33 & Düne-Süd & 16.5 & $16-09-87$ & 5 & - & 100 & sandstone \\
\hline 22 & West Seite & 6.3 & $02-09-87$ & 65 & 70 & 75 & sandstone \\
\hline 24 & Repulsegrund & 11.1 & $03-09-87$ & 95 & 110 & 75 & limestone \\
\hline 50 & Nordhafenknoll & 7.3 & $19-07-87$ & 90 & 220 & 75 & limestone \\
\hline 25 & Sellebrunnknoll & 15.1 & $04-09-87$ & 45 & 30 & 75 & limestone \\
\hline 64 & Repulsegrund & 10.6 & $08-06-89$ & 100 & 40 & 75 & limestone \\
\hline 70 & Sellebrunnknoll & 12.4 & $13-06-89$ & 90 & 250 & 75 & limestone \\
\hline 75 & West Seite & 11.7 & $20-06-89$ & 20 & 310 & 75 & limestone \\
\hline 80 & Sellebrunnknoll & 12.2 & $27-06-89$ & 80 & 180 & 75 & limestone \\
\hline 67 & Repulsegrund & 14.7 & $12-06-89$ & 30 & 30 & 75 & limestone \\
\hline \multicolumn{8}{|c|}{ Community E } \\
\hline 13 & Nordmole & 22.9 & $23-07-87$ & 5 & 240 & 100 & sandstone \\
\hline 40 & Düne-Süd & 15.5 & $07-07-88$ & 10 & - & 100 & sandstone \\
\hline 48 & Nordreede-West & 11.9 & $14-07-88$ & 5 & - & 75 & sandstone \\
\hline 71 & West Seite & 19.5 & $14-06-89$ & 60 & 210 & 75 & sandstone \\
\hline 79 & Repulsegrund & 19.6 & $26-06-89$ & 25 & 30 & 75 & sandstone \\
\hline 38 & Düne-Süd & 12.6 & $06-07-88$ & 20 & 60 & 100 & limestone \\
\hline 46 & Nordmole & 18.3 & $13-07-88$ & 60 & 300 & 75 & sandstone \\
\hline 68 & Nordmole & 14.3 & $12-06-89$ & 30 & 270 & 75 & sandstone \\
\hline 74 & Steingrund & 10.2 & $19-06-89$ & 0 & - & 75 & sandstone \\
\hline 45 & Düne-Süd & 19.2 & $12-07-88$ & 60 & 150 & 75 & sandstone \\
\hline \multicolumn{8}{|c|}{ Community $F$} \\
\hline 27 & Nordreede-West & 9.3 & $08-09-87$ & 10 & 0 & 100 & sandstone \\
\hline 62 & Nordreede-Ost & 10.4 & $06-06-89$ & 20 & 190 & 100 & sandstone \\
\hline 29 & Nordreede-Ost & 9.3 & $09-09-87$ & 10 & - & 75 & sandstone \\
\hline 56 & Nordreede-Ost & 8.0 & $26-07-88$ & 20 & 80 & 75 & sandstone \\
\hline 32 & Nordreede-West & 10.5 & $14-09-87$ & 10 & - & 100 & sandstone \\
\hline 36 & Nordreede-West & 9.5 & $05-07-88$ & 65 & 150 & 100 & sandstone \\
\hline \multicolumn{8}{|c|}{ Community G } \\
\hline 04 & Vorhafen & 7.3 & $10-07-87$ & 90 & 0 & 100 & concrete \\
\hline 15 & Vorhafen & 6.3 & $27-07-87$ & 90 & 210 & 100 & concrete \\
\hline 11 & Vorhafen & 7.4 & $22-07-87$ & 90 & 30 & 100 & concrete \\
\hline 55 & Vorhafen & 7.1 & $22-07-88$ & 90 & 20 & 75 & concrete \\
\hline 77 & Vorhafen & 6.1 & $21-06-89$ & 90 & 50 & 75 & concrete \\
\hline 26 & Vorhafen & 6.5 & $07-09-87$ & 5 & - & 75 & sandstone \\
\hline \multicolumn{8}{|c|}{ Community $\mathrm{H}$} \\
\hline 57 & Südhafen & 4.2 & $26-07-88$ & 90 & 120 & 75 & iron \\
\hline 60 & Südhafen & 4.5 & $27-07-88$ & 90 & 120 & 75 & iron \\
\hline 66 & Südhafen & 5.1 & 09-06-89 & 90 & 80 & 75 & iron \\
\hline
\end{tabular}




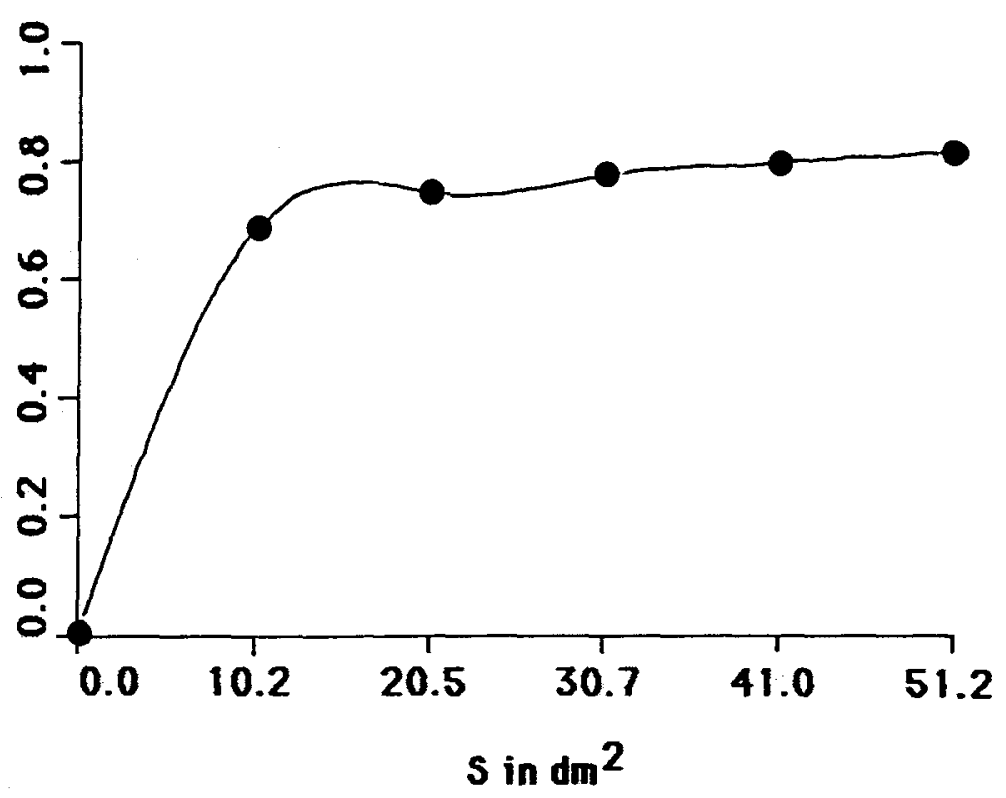

Fig. 2. Bray-Curtis coefficient (SI) as a function of the sampled surface (S) for station 2 (West Seite$9.9 \mathrm{~m}$ depth)

the minimal sampling area is independent of the quadrat size, it is larger in a patchily distributed community than in a homogeneously distributed community. Station 2 is dominated by the anthozoan Metridium senile, a species which tends to occur in a patchy distribution. The area of 3 to 4 quadrats of $50 \times 50 \mathrm{~cm}\left(75-100 \mathrm{dm}^{2}\right)$ is therefore certainly sufficient to yield a representative sample of the communities off Helgoland.

\section{Environmental parameters}

The submarine daylight was measured using a relative "Underwater Hemispherical Irradiance Meter" (UHIM) described by Weinberg (1979). The spectral sensitivity of the UHIM (peak value $480 \mathrm{~nm}$; band-width $60 \mathrm{~nm}$ ) roughly corresponds to the transmission characteristics of water. From the measurements in midwater, the vertical extinction coefficient $\left(k\right.$ in $\left.\mathrm{m}^{-1}\right)$ was calculated, using the Lambert-Beer law [Eq. (1)] for monochromatic light.

$$
\mathrm{I}_{\mathrm{d}}=\mathrm{I}_{0} \cdot \mathrm{e}^{-k \mathrm{kt}}
$$

From measurements at the stations and at the same depth in midwater, the station coefficient ( $\mathrm{sc}$ in \%) of each station was obtained.

The exposure of the sublittoral communities to water movement was determined in two ways. For some stations, the rate of exposure was related to the erosion of gypsum blocks. The erosion value is expressed as the average weight loss of four gypsum blocks $\left(\mathrm{g} \cdot \mathrm{h}^{-1}\right)$ during one lunar day $(24.45 \mathrm{~h})$. A description of this method, including a mathematical framework, is given by De Kluijver \& Kaandorp (in prep.). A second 


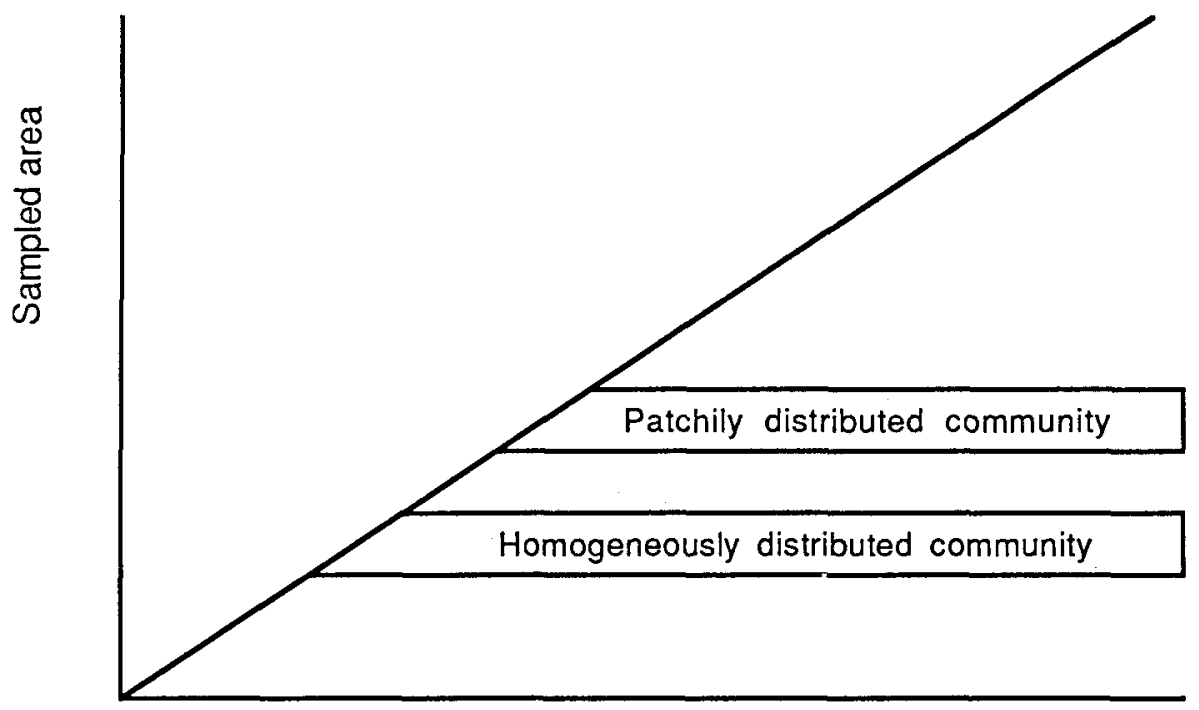

Quadrat size

Fig. 3. Computer simulated determination of the minimal area of a homogeneously and a patchily distributed community. For explanation see text

method, which was performed for all stations, used the sediment characteristics as an indicator of the exposure to water movement. In order to determine these sediment characteristics, samples of about $100 \mathrm{~g}$ of the upper $1 \mathrm{~cm}$ layer of the sediments were sieved through 7 graded sieves $(2.8-0.053 \mathrm{~mm})$. The characteristics were expressed as the proportional contribution of the dry weight of the different sieved fractions. The contribution of the various fractions was analysed with non-transformed data, using the computer programs CLUSTAN1C2 (Wishart, 1978) and SRTORD (Kaandorp, 1986). The lower marginal value of the smallest characteristic fraction was used as an indication of the current velocity.

The potential sedimentation in the communities was measured using sediment traps. As advised by Bloesch \& Burns (1980), simple cylinders were used with an inner diameter of $11.7 \mathrm{~cm}$. Because of the bottom relief, the ratio of length to diameter was restricted to $5: 1$. Sedimentation was expressed in $\mathrm{g} \cdot \mathrm{m}^{-2} \cdot \mathrm{d}^{-1}$, dry weight, measured over 21 days.

Temperature was measured using a modified mercury thermometer (Weinberg, 1979). Both the surface and bottom temperature were measured at each station. Additional data were obtained from the weather station Helgoland.

\section{Cluster analysis and inverse analysis}

For the cluster analysis, the percentage cover of all sessile organisms of the quadrats of a station was averaged. This yielded a data table of 80 stations and 142 sessile species. Before analysis, all data were logarithmically transformed using Eq. (2); in which $\mathrm{x}$ is the percentage cover and $\mathrm{T}(\mathrm{x})$ the transformed value. 


$$
\begin{array}{ll}
\mathrm{x}=0.0 & \rightarrow \mathrm{T}(\mathrm{x})=0 \\
0.1 \leq \mathrm{x} \leq 100.0 & \rightarrow \mathrm{T}(\mathrm{x})=\log (10 \mathrm{x})+1
\end{array}
$$

The cluster analysis was carried out using the computer program CLUSTAN1C2 (Wishart, 1978). The Average Linkage method (Sokal \& Michener, 1958) was used in combination with the Bray-Curtis coefficient [Eq. (3)].

$$
S(X, Y)=\frac{\sum_{i=1}^{m}|X i-Y i|}{\sum_{j=1}^{m}(X j+Y j)}
$$

This combination of algorithm and coefficient leads to reproducible results (Shin, 1982; Kaandorp, 1986; De Kluijver, 1989; De Kluijver et al., in prep.).

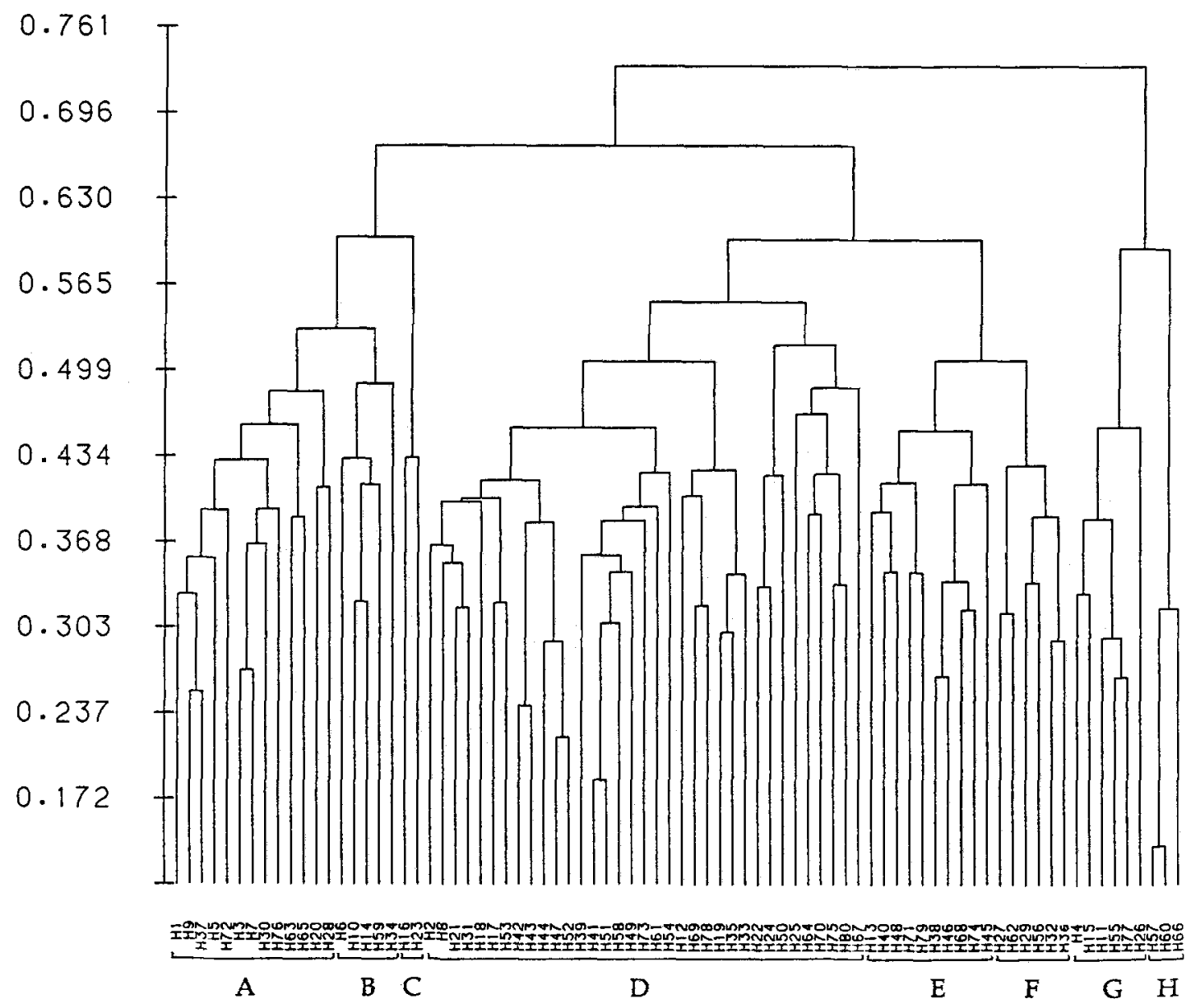

Fig. 4. Dendrogram resulting from the cluster analysis of the data. The clusters distinguished are marked A-H 
In addition to the normal analysis an inverse analysis was performed, which procures information about the composition of the clusters. With the program SRTORD (Kaandorp, 1986), the distribution of the quantities of the species over the clusters was calculated. Characteristic species were distinguished at a concentration level of $90 \%$ within a community. Dominant and characteristic species must be present in at least $67 \%$ of the stations with the community concerned.

For comparison, the data were also analysed using the program TWINSPAN (Hill, 1979), with the following input parameters: for pseudospecies the cut levels $0.0,2.0,5.0$, 10.0 and 20.0 were used, and all weights for levels of pseudospecies were set to 1 , without indicator potentials for the cut levels.

\section{RESULTS}

\section{Cluster analysis and inverse analysis}

Figure 4 shows the dendrogram resulting from cluster analysis, the ordered diagrams resulting from the inverse analysis are given in Tables $3,4,5,6$ and 7 . Three main groups of stations can be discriminated using the fixed stopping rule. The first cluster (A, B and C) consists of stations sampled in the photic zone, between 2.1 and $10.8 \mathrm{~m}$, dominated by algae. The second cluster ( $D, E$ and $F$ ) is formed by stations sampled in the aphotic zone, between 6.3 and $22.9 \mathrm{~m}$. The third cluster $(\mathrm{G}$ and $\mathrm{H})$ is sampled in the sheltered, artificially constructed, Vor- and Südhafen, between 4.2 and $7.4 \mathrm{~m}$.

A further division, using the variable stopping rule, yields 8 meaningful clusters which can be regarded as sublittoral communities on account of species composition and differences in the environmental parameters. The variable stopping rule is preferred to the fixed stopping rule, because it allows differences in the mosaic composition of the species in the different communities, which lead to different similarity levels.

\section{Environmental parameters}

The southern North Sea water mixes with fresh water supplied by the rivers Elbe and Weser, which causes a decrease in salinity towards the coast. During spring, the salinity of the surface water at Helgoland may decrease to $30-31 \%$. S, while during wintertime the salinity may increase to $34 \% \mathrm{~S}$ (Hagmeier, 1930). The annual changes in temperature of the surface water ranges from $2^{\circ} \mathrm{C}$ to $18^{\circ} \mathrm{C}$ (Lüning, 1985). Salinity and temperature values for 1986 are given by Gillbricht (1987). The fluctuations of salinity and temperature at greater depths (Tiefe Rinne, 50 to $60 \mathrm{~m}$ ) are smaller than in the surface layer (Klöckner, 1976).

The current pattern around Helgoland is strongly influenced by the geomorphology of the sea bed. Integrated measurements of the total amount of water movement, using gypsum blocks, were performed during July 15-16, 1987 on a calm day. The west side of Helgoland is the most exposed $\left(0.14-0.16 \mathrm{~g} \cdot \mathrm{h}^{-1}\right)$, followed by the Nordreede $\left(0.14 \mathrm{~g} \cdot \mathrm{h}^{-1}\right)$ and Düne-Kalberdans and Vorhafen $\left(0.10 \mathrm{~g} \cdot \mathrm{h}^{-1}\right)$. In shallow places (station 3, West Seite, depth $6.0 \mathrm{~m}$ ), this value rapidly increased during stormy weather conditions. Measurements during July 23-24, 1987 (westerly wind, force 4-5) show erosion values of 0.28 $\mathrm{g} \cdot \mathrm{h}^{-1}$. The prevailing winds around Helgoland are westerly (Fig. 5). The influence of 
wind induced water movement can almost be neglected at a depth of half the wave length (Van Straaten, 1973).

The current velocity also influences the particle size of deposited material. Cluster analysis of 88 sediment samples yielded a dendrogram with 7 different types of sediments. The result of the inverse analysis is given in Table 2 . The sequence in the ordered diagram is that of decreasing dominance of the coarse fractions. Sediment type $I$ is characterized by a dominance of the coarse sand fraction $(2.8-1.4 \mathrm{~mm})$, while type VII is characterized by the dominance of silt and clay fractions $(<0.15 \mathrm{~mm})$. Below the diagram, the proportional contribution of stations of different communities are listed. The sequence of the communities, ordered according to the fineness of the sediments, corresponds with the results of the exposure experiments using gypsum blocks. The potential sedimenta-

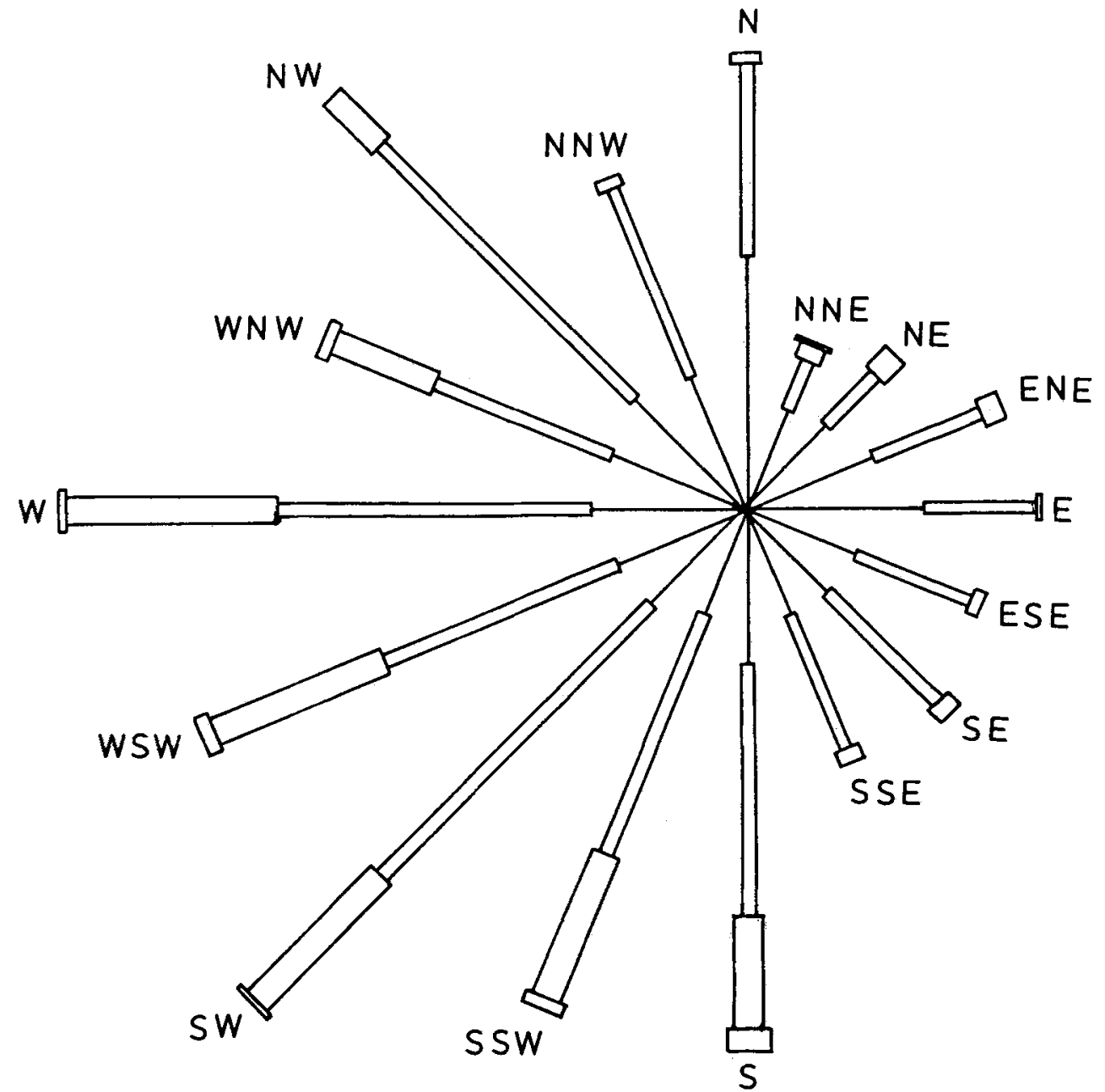

Fig. 5. Wind energy rose for Helgoland for 1983 (data from Wetterstation Helgoland). Increased thickness of lines indicates strengths of $1-3,4-5,6-7$ and more than 8 Beaufort 
Table 2. Ordered diagram resulting from the inverse analysis of the sediment data and the proportional contribution of the different sediment types over the communities. *** The clusters in which a concentration level of $90 \%$ is reached

\begin{tabular}{|c|c|c|c|c|c|c|c|}
\hline Type & I & II & III & IV & $\mathrm{V}$ & VI & VII \\
\hline $02.8-01.4$ & $\cdots$ & $\cdots$ & $* *$ & & $\cdots$ & & \\
\hline $01.4-0.60$ & & $\cdots$ & $\cdots$ & & $\cdots$ & $\cdots$ & \\
\hline $0.60-0.30$ & & & $* * *$ & $\cdots$ & $\cdots$ & $* * *$ & \\
\hline $0.30-0.15$ & & & & $\cdots$ & $\cdots$ & $\cdots$ & \\
\hline $0.15-0.09$ & & & & $\cdots$ & $\cdots$ & $\cdots$ & $\cdots$ \\
\hline $0.09-0.05$ & & & & & $\cdots$ & $\cdots$ & $\cdots$ \\
\hline$<0.05$ & & & & & & $\cdots$ & $\cdots$ \\
\hline \multicolumn{8}{|c|}{ Community } \\
\hline B & 40.0 & 40.0 & 20.0 & - & - & - & - \\
\hline D & 3.3 & 56.7 & 33.3 & - & 6.7 & - & - \\
\hline C & - & 100.0 & - & - & - & - & - \\
\hline E & - & 55.5 & 11.1 & - & 33.3 & - & - \\
\hline A & - & 33.3 & - & 8.3 & 58.3 & - & - \\
\hline F & - & 20.0 & - & - & 60.0 & 20.0 & - \\
\hline $\mathrm{G}$ & - & - & 16.7 & - & 16.7 & 66.7 & - \\
\hline $\mathrm{H}$ & - & - & - & - & - & 100.0 & - \\
\hline
\end{tabular}

tion in the natural environment varied between 19.5 and $42.1 \mathrm{~g} \cdot \mathrm{m}^{-2} \cdot \mathrm{d}^{-1}$, while in the artificially constructed harbours this amounted to $65.1 \mathrm{~g} \cdot \mathrm{m}^{-2} \cdot \mathrm{d}^{-1}$ in the Vorhafen and only $13.7 \mathrm{~g} \cdot \mathrm{m}^{-2} \cdot \mathrm{d}^{-1}$ in the Südhafen. In all samples, more than $75 \%$ of the sediment consists of fractions smaller than $0.05 \mathrm{~mm}$. In Figure 6, the proportional contribution of the dry weights is plotted against the different fractions. Table 2 clearly shows that in the natural environment the lower limit of the characteristic fraction is almost larger than 0.09

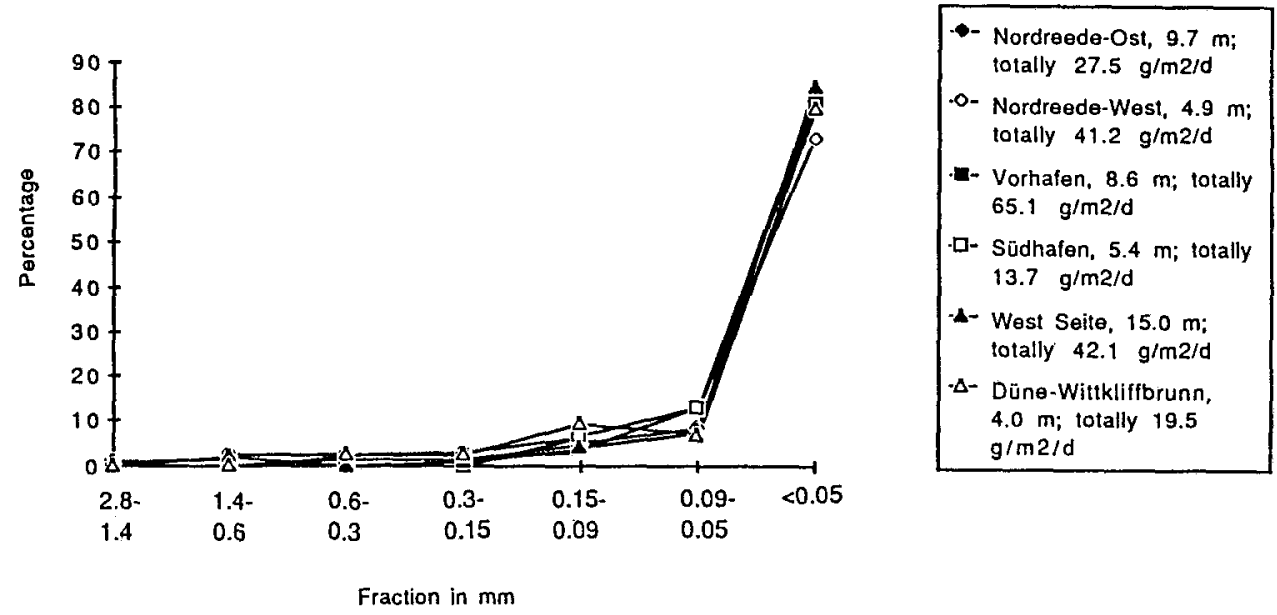

Fig. 6. Proportional contribution of the dry weights of the different fractions in the sediment traps 


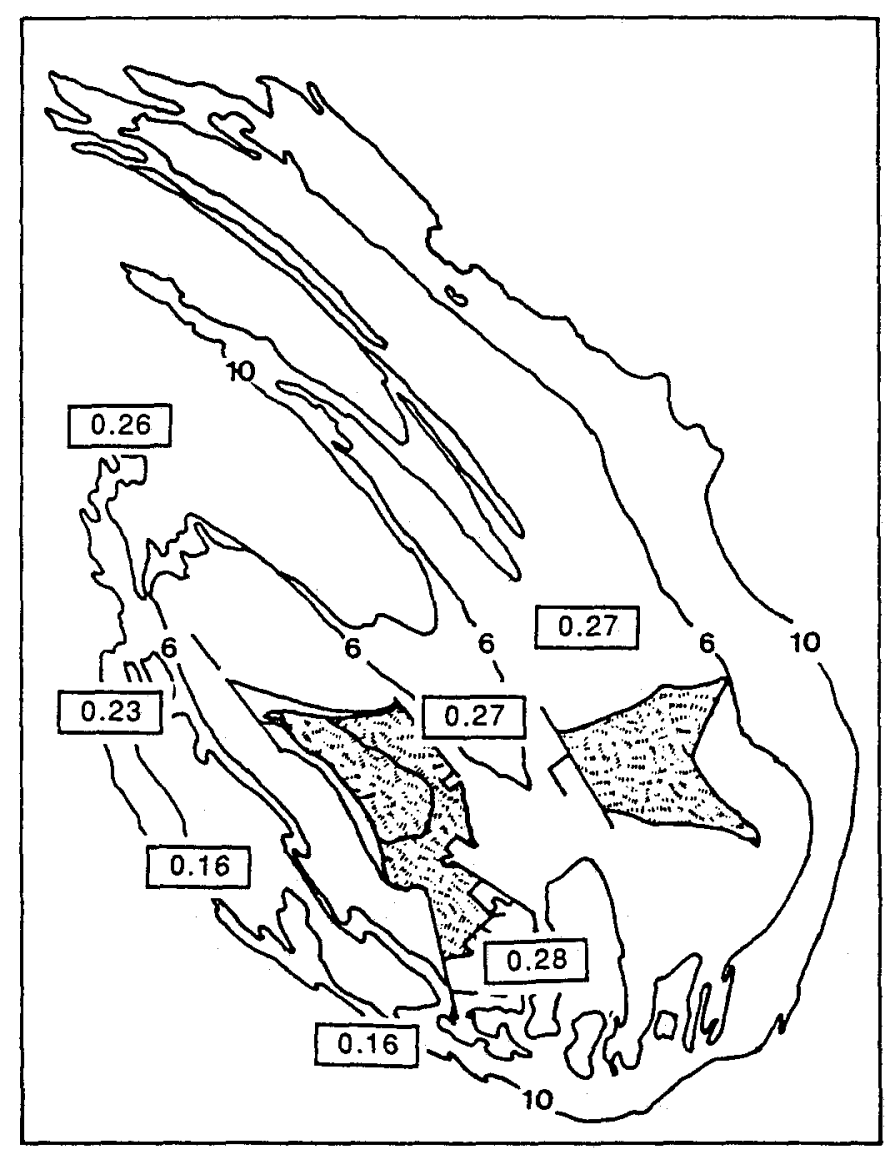

Fig. 7. Minimal vertical extinction coefficients $\left(\mathrm{k} \mathrm{m}^{-1}\right)$ in midwater measured in July 1987

$\mathrm{mm}$, while in the artificial environment the lower limit of the characteristic fraction is generally smaller than $0.05 \mathrm{~mm}$. This implies that in the natural environment erosion takes place, while in the harbours sedimentation occurs.

Light-penetration is strongly influenced by seasonal changes and weather conditions (Lüning \& Dring, 1979). Figure 7 shows the lowest values of the vertical extinction coefficient measured in July 1987. Localities on the relatively shallow east side of Helgoland show higher values of the vertical extinction coefficient than localities on the west side. Through stirred up sediments and erosion products, the vertical extinction coefficient increased to $0.59 \mathrm{~m}^{-1}$ during stormy weather in July 1987.

Around Helgoland, three main types of natural hard substrates occur: red sandstone, muchselkalk and limestone facies (Wills, 1968). Two additional types of artificial substrates were sampled: concrete at Kringel and in the Vorhafen, and iron in the Südhafen. 
Table 3. Ordered diagram resulting from the inverse analysis for the species occurring in both the natural environment and the artificially created harbours. The clusters in which a concentration level of $90 \%$ is reached are marked with ..."' or '-..-'. Printed asterisks indicate a presence level of at least $67 \%$ within the communities. Abbreviations: $\mathrm{An}-$ anthozoan, $\mathrm{Br}$ - bryozoan, $\mathrm{BA}$ - brown alga, $\mathrm{Bi}$ - bivalve, $\mathrm{Cr}$ - crustacean, GA - green alga, Hy - hydrozoan, P - polychaete, RA - red alga, S sponge, $\mathrm{T}$ - tunicate, $\mathrm{TL}$ - top layer, $\mathrm{ML}$ - middle layer and $\mathrm{EL}$ - encrusting layer

\begin{tabular}{|c|c|c|c|c|c|c|c|c|}
\hline Community: & A & B & $\mathrm{C}$ & $\mathrm{D}$ & E & $\mathrm{F}$ & G & $\mathrm{H}$ \\
\hline Tubicolous organisms $(\mathrm{Cr} / \mathrm{P})$ & $\cdots$ & $\cdots$ & & $\cdots$ & & & $\cdots$ & $\cdots$ \\
\hline EL-Phymatolithon sp. (RA) & $\cdots$ & & & & $-\cdots-$ & $\cdots$ & $\cdots$ & \\
\hline Audouinella membranacea (RA) & $\cdots$ & $\cdots$ & & $\cdots$ & & & $\cdots$ & *** \\
\hline EL-Hildenbrandia rubra (RA) & $\cdots$ & & & $\cdots$ & $\cdots$ & $\cdots$ & $\cdots$ & \\
\hline Obelia dichotoma $(\mathrm{Hy})$ & $\cdots$ & & & $\cdots$ & $\cdots$ & ---- & $\cdots$ & $\cdots$ \\
\hline Leucosolenia variabilis $(\mathrm{S})$ & & $--\cdot$ & & $* *$ & & & $\cdots$ & $\cdots$ \\
\hline Urticina felina (An) & $\cdots$ & $\cdots$ & & $\cdots$ & & & --- & \\
\hline Alcyonium digitatum (An) & & $\cdots$ & & $* *$ & $* *$ & & $\cdots$ & \\
\hline Scypha ciliata (S) & $\cdots$ & & & $\cdots$ & & & $* *$ & $\cdots$ \\
\hline Didemnum maculosum (T) & $\cdots$ & & & --- & & & $\cdots$ & \\
\hline Botrylloides leachi $(\mathrm{T})$ & $\cdots$ & $\cdots$ & $\cdots$ & $\cdots$ & & & $\cdots$ & \\
\hline Haliclona rosea (S) & $\cdots$ & & & $\cdots$ & & & $\cdots$ & \\
\hline Clytia hemisphaerica (Hy) & $-\cdots$ & & & $\cdots$ & $\cdots$ & & & $\cdots$ \\
\hline Ulva lactuca (GA) & --- & & & & & --- & --- & \\
\hline Halichondria panicea (S) & --- & $\cdots$ & $\cdots$ & & & & $\cdots$ & $\cdots$ \\
\hline Polysiphonia urceolata (RA) & $\cdots$ & $\cdots$ & $\cdots$ & & & & $\cdots$ & \\
\hline Phyllophora pseudoceranoides (RA) & $\cdots$ & $\cdots$ & $\cdots$ & & & & $\cdots$ & \\
\hline Ceramium deslongchampsii (RA) & --.- & $\cdots$ & & & & & $\cdots$ & $\cdots$ \\
\hline Ceramium rubrum (RA) & $\cdots$ & $\cdots$ & & & & & $\cdots$ & \\
\hline Enteromorpha linza (RA) & $\cdots$ & $\cdots$ & & & & & & $\cdots$ \\
\hline Sidnyum turbinatum $(\mathrm{T})$ & $\cdots$ & $\cdots$ & & & & & $\cdots$ & \\
\hline Callithamnion hookeri (RA) & $\cdots$ & & & & & & & $\cdots$ \\
\hline Phycodrys rubens (RA) & $\cdots \cdot-$ & $\cdots$ & & & & & $\cdots$ & \\
\hline Desmarestia viridis (BA) & $\cdots$ & $\cdots$ & & & & & & $\cdots$ \\
\hline Alcyonidium mytili $(\mathrm{Br})$ & & -.- & & & & & & -..- \\
\hline Bryopsis lyngbyei (GA) & $\cdots$ & & & & & & & -..- \\
\hline Sphacelaria plumosa (BA) & $\cdots$ & $\cdots$ & & & & & $\cdots$ & \\
\hline Dynamena pumila (Hy) & $-\cdots$ & $\cdots$ & & & & & $\cdots$ & \\
\hline Lomentaria clavellosa (RA) & $\cdots$ & & & & & &.-- & \\
\hline Spirorbis sp. (P) & $\cdots$ & & & & & & $\cdots$ & \\
\hline Chaetomorpha melagonium (GA) & $\cdots$ & $-\cdots$ & --- & & & & $\cdots$ & \\
\hline \multirow{7}{*}{$\begin{array}{l}\text { Scrupocellaria scruposa }(\mathrm{Br}) \\
\text { Bowerbankia sp. }(\mathrm{Br}) \\
\text { Bugula plumosa }(\mathrm{Br}) \\
\text { EL-Cryptosula pallasiana }(\mathrm{Br})\end{array}$} & & & & --- & & & $\cdots$ & \\
\hline & & & & & $\cdots$ & & & ${ }^{* *}$ \\
\hline & & & & $\cdots$ & $\ldots$ & & $\cdots$ & \\
\hline & \multicolumn{6}{|c|}{ Table 4} & & \\
\hline & \multicolumn{3}{|c|}{ Table 5} & & & & & \\
\hline & & & & \multicolumn{3}{|c|}{ Table 6} & & \\
\hline & & & & & & & \multicolumn{2}{|c|}{ Table 7} \\
\hline
\end{tabular}




\section{The sublittoral communities}

In the dendrogram (Fig. 4), eight sublittoral communities, forming three main groups, are distinguished. The contribution of different taxa to the community composition, split up for the different structural layers, are listed in Table 9. Species characteristic of both the natural offshore environment and the artificially created harbours are listed in Table 3. Species restricted to the photic and aphotic zone in the natural environment are given in Table 4 .

Table 4. Ordered diagram resulting from the inverse analysis for species restricted to the natural environment. For an explanation of the abbreviations and symbols see Table 3

\begin{tabular}{|c|c|c|c|c|c|c|c|c|}
\hline Community: & A & B & $\mathrm{C}$ & D & $\mathrm{E}$ & F & $\mathrm{G}$ & $\mathrm{H}$ \\
\hline Sagartia elegans/troglodytes (An) & $\cdots$ & $\cdots$ & ...- & $\cdots$ & & $\cdots$ & & \\
\hline Sertularia cupressina $(\mathrm{Hy})$ & $\cdots$ & $\cdots$ & & ... & & & & \\
\hline Obelia geniculata $(\mathrm{HY})$ & $\cdots$ & & $\cdots$ & $\cdots$ & & & & \\
\hline Celleporella hyalina $(\mathrm{Br})$ & $\cdots$ & $\cdots$ & ...- & .... & & & & \\
\hline Calicella syringa (Hy) & $\ldots$ & $\cdots$ & & $\cdots$ & $\ldots$ & & & \\
\hline Diphasia rosea (Hy) & -..- & $\cdots$ & & $\cdots$ & $\ldots$ & & & \\
\hline Flustra foliacea (Br) & & $\cdots$ & & $\cdots$ & & & & \\
\hline EL-Electra pilosa (Br) & $\cdots$ & & & .... & *** & & & \\
\hline Phyllophora traillii (RA) & & $\cdots$ & & $\cdots$ & & & & \\
\hline Mytilus edulis (Bi) & -... & $\ldots$ & $\cdots$ & $\ldots$ & & & & \\
\hline Crisia eburnea (Br) & & $\cdots$ & & $\cdots$ & & & & \\
\hline EL-Flustra foliacea $(\mathrm{Br})$ & & $\ldots$ & & $\cdots$ & $\cdots$ & & & \\
\hline EL-Callopora lineata $(\mathrm{Br})$ & -.-- & & & $\cdots$ & $\cdots$ & $\cdots$ & & \\
\hline Diadumene cincta (An) & & -... & & $\ldots$. & $* *$ & $\ldots$ & & \\
\hline Verruca stroemia $(\mathrm{Cr})$ & $\cdots$ & & & $\cdots$ & $\cdots$ & & & \\
\hline Punctaria plantaginea (BA) & ---- & $\ldots$ & & & & .... & & \\
\hline Ectocarpus sp. (BA) & -.-- & ...- & & & & .... & & \\
\hline Sertularella rugosa $(\mathrm{Hy})$ & & --- & & $\cdots$ & & $\cdots$ & & \\
\hline Tubularia larynx (Hy) & & $\ldots$ & & $\cdots$ & ---- & & & \\
\hline Myxilla incrustans (S) & & -..-- & & .... & -..- & & & \\
\hline Sertularella polyzonias (Hy) & & -... & & $\cdots$ & $\cdots$ & & & \\
\hline Crisia denticulata $(\mathrm{Br})$ & & $\cdots$ & & $\cdots$ & & & & \\
\hline Alcyonidium diaphanum $(\mathrm{Br})$ & & .... & & $\cdots$ & & & & \\
\hline Polyplumularia setacea $(\mathrm{Hy})$ & ...- & .... & ...- & .... & & & & \\
\hline Hydrallmania falcata $(\mathrm{Hy})$ & -.-- & $-\cdots$ & & $\cdots$ & & & & \\
\hline Eudendrium sp. (Hy) & -..- & & & $-\cdots$ & ---- & -.-- & & \\
\hline Lanice conchilega (P) & .... & & & -... & & .... & & \\
\hline Janua sp. (P) & $\ldots$ & & & & & ...- & & \\
\hline EL-Cribrilina punctata $(\mathrm{Br})$ & -.-- & & & $\cdots$ & $\cdots$ & .... & & \\
\hline EL-Celleporella hyalina (Br) & -..- & & ...- & $\cdots$ & --.- & ---- & & \\
\hline EL-Microporella ciliata $(\mathrm{Br})$ & .... & & & & -... & .... & & \\
\hline EL-Chorizopora brongniartella $(\mathrm{Br})$ & $-\ldots$ & & & & & -..- & & \\
\hline EL-Conopeum reticulum $(\mathrm{Br})$ & & & $\cdots$ & $\ldots$ & $\cdots$ & $-\ldots$ & & \\
\hline EL-Schizomavella linearis $(\mathrm{Br})$ & -..- & & & $\ldots$ & & & & \\
\hline EL-Alcyonidium mytili $(\mathrm{Br})$ & & --- & & $\cdots$ & & & & \\
\hline
\end{tabular}




\section{Communities restricted to the photic zone}

The first main cluster (A, B and C) is composed of three communities. Table 5 shows the ordered diagram for this cluster. All communities are dominated by algae in the middle layer. The cluster does not possess many collective red algae restricted to this cluster, because most of the dominant algae also occur in the sheltered Vorhafen, e.g. the red algae Polysiphonia urceolata, Phyllophora pseudoceranoides, Ceramium rubrum and Ceramium deslongchampsii (cf. Table 3).

Community $\mathrm{A}$ is found at the localities Nordreede-West, Düne-Kalberdans, West Seite, Kringel, Nordhafenknoll, Nordmole and Skittgatt. With the exception of a deep station at Skittgatt $(10.8 \mathrm{~m})$, all stations possess a well developed top layer of the brown

Table 5. Ordered diagram resulting from the inverse analysis for species restricted to the photic zone in the natural environment. For an explanation of the abbreviations and symbols see Table 3

\begin{tabular}{|c|c|c|c|c|c|c|c|c|}
\hline Community: & A & B & $\mathrm{C}$ & $\mathrm{D}$ & $\mathrm{E}$ & $\mathrm{F}$ & $\mathrm{G}$ & $\mathrm{H}$ \\
\hline Electra pilosa $(\mathrm{Br})$ & $\cdots$ & $\cdots$ & $\cdots$ & & & & & \\
\hline TL-Laminaria hyperborea (BA) & $\cdots$ & & $\cdots$ & & & & & \\
\hline Laminaria hyperborea (BA) & $\cdots$ & & $\cdots$ & & & & & \\
\hline Delesseria sanguinea (RA) & $\cdots$ & $\cdots$ & & & & & & \\
\hline Membranipora membranacea $(\mathrm{Br})$ & $\cdots$ & $\ldots$ & $\cdots$ & & & & & \\
\hline Ulva sp. (GA) & $\cdots$ & $\cdots$ & $\cdots$ & & & & & \\
\hline $\begin{array}{l}\text { Laomedea flexuosa (Hy) } \\
\text { TL-Laminaria saccharina (BA) }\end{array}$ & $\cdots$ & & $\ldots$ & & & & & \\
\hline Laminaria saccharina (BA) & $\ldots$ & & $-\cdots$ & & & & & \\
\hline Corallina officinalis (RA) & $-\cdots$ & & $\cdots$ & & & & & \\
\hline Plocamium cartilagineum (RA) & $-\cdots$ & $\cdots$ & & & & & & \\
\hline Polysiphonia nigra (RA) & $\cdots$ & $\cdots$ & & & & & & \\
\hline Cladophora rupestris (GA) & --- & --- & & & & & & \\
\hline Enteromorpha prolifera (GA) & $\cdots$ & $\cdots$ & & & & & & \\
\hline $\begin{array}{l}\text { Desmarestia aculeata (BA) } \\
\text { Elachista sp. (BA) }\end{array}$ & $\cdots$ & $\cdots$ & & & & & & \\
\hline Membranoptera alata (RA) & $\cdots$ & & & & & & & \\
\hline Porphyra umbilicalis (RA) & $\cdots$ & & & & & & & \\
\hline Sphacelaria radicans (BA) & $\cdots$ & & & & & & & \\
\hline Petalonia fascia (BA) & $\cdots$ & & & & & & & \\
\hline $\begin{array}{l}\text { Acervochalina loosanoffi (S) } \\
\text { EL-Ralfsia verrucosa (BA) }\end{array}$ & $\cdots$ & & & & & & & \\
\hline EL-Membranipora membranacea $(\mathrm{Br})$ & --- & & & & & & & \\
\hline Polyides rotundus (RA) & & $-\ldots$ & & & & & & \\
\hline Polysiphonia nigrescens (RA) & & $\ldots$ & & & & & & \\
\hline Cladophora albida (GA) & & --- & & & & & & \\
\hline Polyclinum aurantium $(\mathrm{T})$ & & --- & & & & & & \\
\hline Molgula citrina (T) & & $\cdots$ & & & & & & \\
\hline Esperiopsis fucorum (S) & & & $\cdots$ & & & & & \\
\hline Sphacelaria caespitosa (BA) & & & & & & & & \\
\hline
\end{tabular}


alga Laminaria hyperborea. The middle layer is dominated by red algae (dominant species: Ceramium rubrum and Delesseria sanguinea), brown algae (dominant species: Laminaria hyperborea) and tubicolous organisms. These tubicolous organisms belong to different taxa of Crustacea (Amphipoda, for instance Jassa falcata and corophiids) and Polychaeta (Spionidae, for instance Polydora ciliata). The red alga Membranoptera alata is characteristic of this community. The bryozoans Membranipora membranacea and Electra pilosa are often epiphytic on Laminaria hyperborea and on red algae, respectively. The encrusting layer is dominated by the red algae Phymatolithon sp. and Hildenbrandia rubra. This community is established on the abrasion terraces around Helgoland and Düne, ranging from 4.7 to $10.8 \mathrm{~m}$. The community is found on sloping substrates $\left(5-30^{\circ}\right)$, composed of red sandstone, limestone and concrete. The exposure to water movement strongly varies with the topographic position in relation to the prevailing winds. Sediments available on the substrates belong to the types II, IV and V. On the west side of Helgoland mainly type II is found, while on the localities between the islands Helgoland and Düne only types IV and V are found. The stations with a well developed top layer extend on the east side of the islands to a depth at which $17 \%$ of the surface light intensity is available and on the west side to a depth at which $13.5 \%$ is available. The station at Skittgatt, lacking a top layer, receives only $5.5 \%$ of the surface light intensity. The amount of daylight received by the middle layer is strongly influenced by the development of the top layer and the slope of the substrate. The station coefficient in this layer varies between 4 and $87.5 \%$.

Community B is found at the localities Kringel and Hamburger Loch. A top layer is lacking. The middle layer is mainly formed by tubicolous organisms, the red alga Phyllophora trailli, the hydrozoan Sertularia cupressina and the tunicate Sidnyum turbinatum. The bryozoan Electra pilosa is found epiphytic and epizoic on the other organisms. The encrusting layer is dominated by bryozoans (dominant species: Alcyonidium mytili). There is hardly any bare substrate left. The community occurs at the top of sublittoral cliffs on the exposed west side of Helgoland at the lower limit of the photic zone, between 9.2 and $10.0 \mathrm{~m}$. The lack of a canopy of Laminaria hyperborea in this community is caused by the diminished light intensity at this depth (see also Lüning, 1970,1985 ). Because of its greater depth, the influence of wave-induced water movement is of less importance. The sediments found in this community belong to the coarse types I, II and III, indicating a stronger tidal current than at the stations of community A. The substrate is composed of red sandstone and limestone. The amount of daylight received by the middle layer varies between 16 and $20 \%$, depending on the angle of inclination of the substrates $\left(10-70^{\circ}\right)$.

Community $C$ is sampled at the location Düne-Wittkliffbrunn, between 2.1 and $3.7 \mathrm{~m}$. This community possesses a well developed canopy of the brown alga Laminaria hyperborea. The middle layer is hardly developed; only Laminaria hyperborea and the epiphytic growth form of Electra pilosa occur in substantial quantities. A characteristic species of this community is the sponge Esperiopsis fucorum. The encrusting structural layer is, like the middle layer, hardly developed. This is probably caused by the nature of the substrate, which is composed of the erosive muschelkalk. The angle of inclination of the substrates varies between 5 and $25^{\circ}$. The sediments belong to type II. The amount of daylight received by the top layer varies between 37 and $57 \%$ of the surface light intensity, The middle structural layer only receives $10 \%$ of this irradiance. 


\section{Communities restricted to the aphotic zone}

The second main cluster (D, E and F) is also composed of three sublittoral communities (cf. diagram in Table 6). Dominant collective species of all three communities are tubicolous organisms, the polychaete Pomatoceros triqueter, the anthozoan Alcyonium digitatum and the encrusting alga Phymatolithon sp.

Community D is found at the localities West Seite, Kringel, Repulsegrund, Nordmole, Sellebrunnknoll, Nordhafenknoll, Hamburger Loch and Düne-Süd between 6.3 and

Table 6. Ordered diagram resulting from the inverse analysis for species restricted to the aphotic zone in the natural environment. For an explanation of the abbreviations and symbols see Table 3

\begin{tabular}{|c|c|c|c|c|c|c|c|c|}
\hline Community: & $\mathrm{A}$ & B & $\mathrm{C}$ & D & E & F & $\mathrm{G}$ & $\mathrm{H}$ \\
\hline $\begin{array}{l}\text { Metridium senile (An) } \\
\text { Tubulipora liliacea }(\mathrm{Br}) \\
\text { EL-Escharella immersa }(\mathrm{Br}) \\
\text { Disporella hispida (Br) } \\
\text { Tubularia indivisa }(\mathrm{Hy}) \\
\text { Kirchenpaueria pinnata }(\mathrm{Hy}) \\
\text { Cliona celata }(\mathrm{S}) \\
\text { Pleraplysilla minchi }(\mathrm{S}) \\
\text { Dendrodoa grossularia }(\mathrm{T}) \\
\text { EL-Electra monostachys }(\mathrm{Br}) \\
\text { EL-Escharella variolosa }(\mathrm{Br}) \\
\text { EL-Membraniporella nitida }(\mathrm{Br}) \\
\text { EL-Alcyonidium mamillatum }(\mathrm{Br})\end{array}$ & & & & 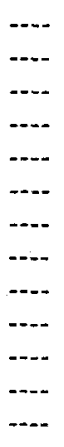 & $\begin{array}{l}\cdots \\
\cdots \\
\cdots \\
\cdots \\
\cdots \\
\cdots- \\
\cdots \\
\cdots \\
\cdots \\
\cdots \\
\cdots\end{array}$ & $\begin{array}{l}\cdots * \\
\cdots \\
\cdots \\
\cdots \\
\cdots \\
\cdots \\
\cdots\end{array}$ & & \\
\hline $\begin{array}{l}\text { Cladophora sericea (GA) } \\
\text { Nolella sp. (Br) } \\
\text { Bicellariella ciliata }(\mathrm{Br}) \\
\text { Bugula flabellata }(\mathrm{Br}) \\
\text { Crisia aculeata }(\mathrm{Br}) \\
\text { Cellepora pumicosa }(\mathrm{Br}) \\
\text { Polymastia mamillaris }(\mathrm{S}) \\
\text { Mycale macilenta }(\mathrm{S}) \\
\text { Haliclona urceolus }(\mathrm{S}) \\
\text { Haliclona oculata }(\mathrm{S}) \\
\text { Oscarella lobularis }(\mathrm{S}) \\
\text { Opercularella lacerata }(\mathrm{Hy}) \\
\text { Halecium halecinum }(\mathrm{Hy}) \\
\text { Zirfaea crispata }(\mathrm{Bi}) \\
\text { Ascidiella scabra }(\mathrm{T}) \\
\text { EL-Cellepora pumicosa }(\mathrm{Br})\end{array}$ & & & & 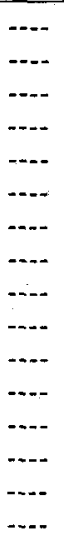 & & & & \\
\hline Pomatoceros triqueter $(\mathrm{P})$ & & & & & $\cdots$ & $\cdots$ & & \\
\hline $\begin{array}{l}\text { Abietinaria abietina (Hy) } \\
\text { Biemna variantia }(\mathrm{S}) \\
\text { EL-Smittina landsborovi }(\mathrm{Br})\end{array}$ & & & & & $\begin{array}{l}\cdots+. \\
\cdots-. \\
\cdots\end{array}$ & & & \\
\hline $\begin{array}{l}\text { Cerianthus lloydii (An) } \\
\text { Lomentaria orcadensis (RA) }\end{array}$ & & & & & & $\cdots$ & & \\
\hline
\end{tabular}




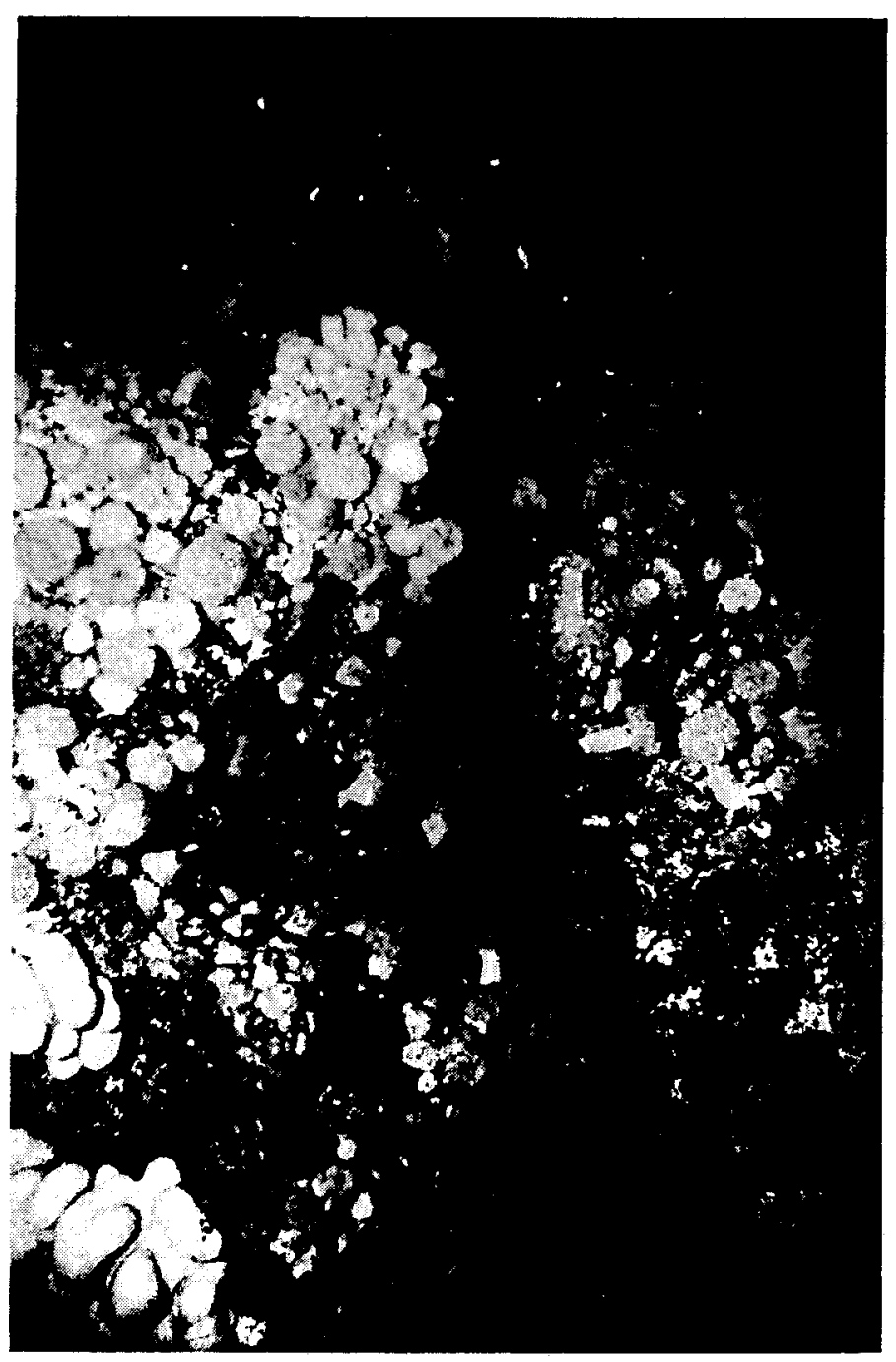

Fig. 8. The variant of community D at West Seite, dominated by Metridium senile. On the left hand side, two contracted colonies of the octocoral Alcyonium digitatum are present (photograph: Marcel Carpay)

$17.3 \mathrm{~m}$. The community lacks a top layer of brown algae. The middle layer is dominated by the anthozoan Metridium senile, the bryozoan Flustra foliacea or tubicolous organisms. The encrusting layer is formed by bryozoans and encrusting red algae. Sediments found in this community belong to the types I, II, III and V. The community is established at relatively shallow depths $(6.3-7.3 \mathrm{~m})$ on vertical cliffs formed by gullies in the abrasion terraces and at greater depths $(9.9-17.3 \mathrm{~m})$. The substrates consist of red sandstone and limestone, sloping between 5 and $100^{\circ}$. The amount of daylight received by this community in the gullies amounts to $5.5 \%$ and varies between 2 and $20.5 \%$ at greater depths. 


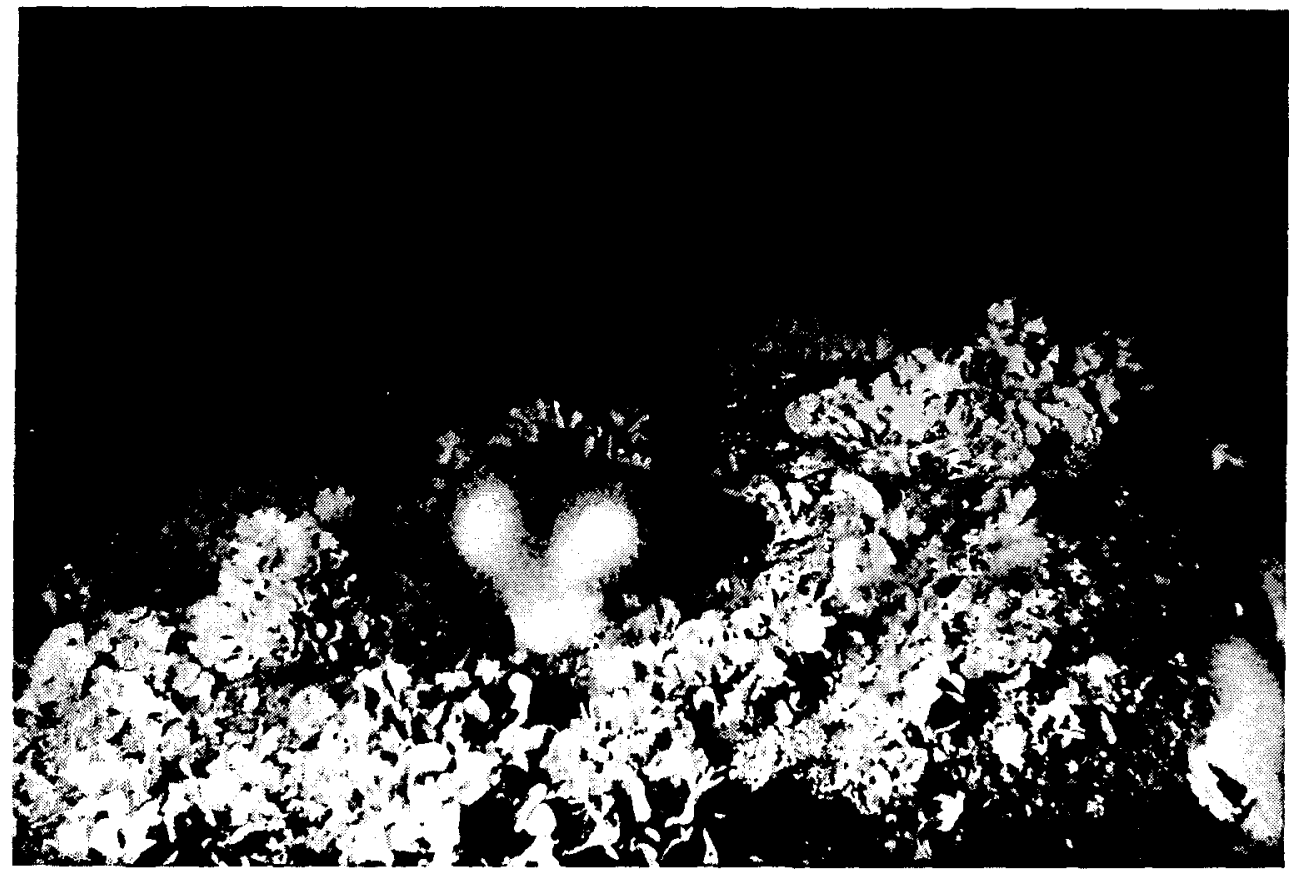

Fig. 9. The variant of community D at West Seite, dominated by Flustra foliacea. In the centre, an expanded colony of the octocoral Alcyonium digitatum is present (photograph: Marcel Carpay)

There are no characteristic species of this community. On account of species abundance, this heterogeneous community can be divided into three physiognomic variants:

The first variant is dominated by the anthozoan Metridium senile (Fig. 8). This variant is established between 6.3 and $15.1 \mathrm{~m}$ on sand- and limestone vertical cliffs. On horizontal and sloping limestone substrates $\left(5-45^{\circ}\right)$, between 11.2 and $15.1 \mathrm{~m}$, a second variant is found, in which tubicolous organisms become more abundant.

On nearly horizontal sandstone substrates $\left(5-10^{\circ}\right)$, between 11.6 and $17.3 \mathrm{~m}$, the third variant is established. This variant is dominated by the bryozoan Flustra foliacea (Fig. 9). The bryozoan Bugula flabellata is restricted to this variant, always epizoic on Flustra foliacea.

Community $E$ is found at the localities Nordmole, Düne-Süd, Nordreede-West, West Seite, Repulsegrund and Steingrund, between 10.2 and $22.9 \mathrm{~m}$. A top layer is not developed in this community. The middle layer is dominated by the polychaete Pomatoceros triqueter. Other dominant species are the octocoral Alcyonium digitatum and the anthozoan Metridium senile. The encrusting layer is formed by the red alga Phymatolithon sp., but also many bryozoan species are found in this layer. The sediments belong to the types II, III and V. The substrate is composed of red sandstone and limestone. The stations are sampled on nearly horizontal substrates $\left(0-30^{\circ}\right)$ and on vertical sides of boulders $\left(60^{\circ}\right)$. The amount of daylight received by the community varies between 0.5 and $16 \%$ of the surface intensity. 
Table 7. Ordered diagram resulting from the inverse analysis for species restricted to the artificially created harbours. For an explanation of the abbreviations and symbols see Table 3

\begin{tabular}{|c|c|c|c|c|c|c|c|c|}
\hline Community: & A & B & $\mathrm{C}$ & $\mathrm{D}$ & $\mathrm{E}$ & $F$ & $\mathrm{G}$ & $\mathrm{H}$ \\
\hline $\begin{array}{l}\text { Barnacles }(\mathrm{Cr}) \\
\text { Botryllus schlosseri }(\mathrm{T}) \\
\text { Bryopsis hypnoides }(\mathrm{GA})\end{array}$ & & & & & & & $\begin{array}{l}\cdots \\
\cdots \\
\cdots\end{array}$ & $\cdots *$ \\
\hline $\begin{array}{l}\text { Clavelina lepadiformis }(\mathrm{T}) \\
\text { Trailliella intricata (RA) } \\
\text { Halichondria bowerbanki (S) } \\
\text { Leuconia johnstoni (S) } \\
\text { Plumaria elegans (RA) } \\
\text { Antithamnion plumula (RA) } \\
\text { Callopora lineata (Br) } \\
\text { Conopeum reticulum (Br) }\end{array}$ & & & & & & & $\begin{array}{l}\cdots * \\
\cdots \\
\cdots \\
\cdots \\
\cdots- \\
\cdots-. \\
\cdots \\
\cdots\end{array}$ & \\
\hline $\begin{array}{l}\text { Sagartiogeton undatus (An) } \\
\text { Ascidiella aspersa (T) } \\
\text { Ciona intestinalis (T) } \\
\text { Codium fragile (tenuous form) (GA) } \\
\text { Cryptosula pallasiana (Br) } \\
\text { Coryne sarsii (Hy) } \\
\text { Suberites ficus (S) }\end{array}$ & & & & & & & & $\begin{array}{l}\cdots \\
\cdots \\
\cdots \\
\cdots \\
\cdots\end{array}$ \\
\hline
\end{tabular}

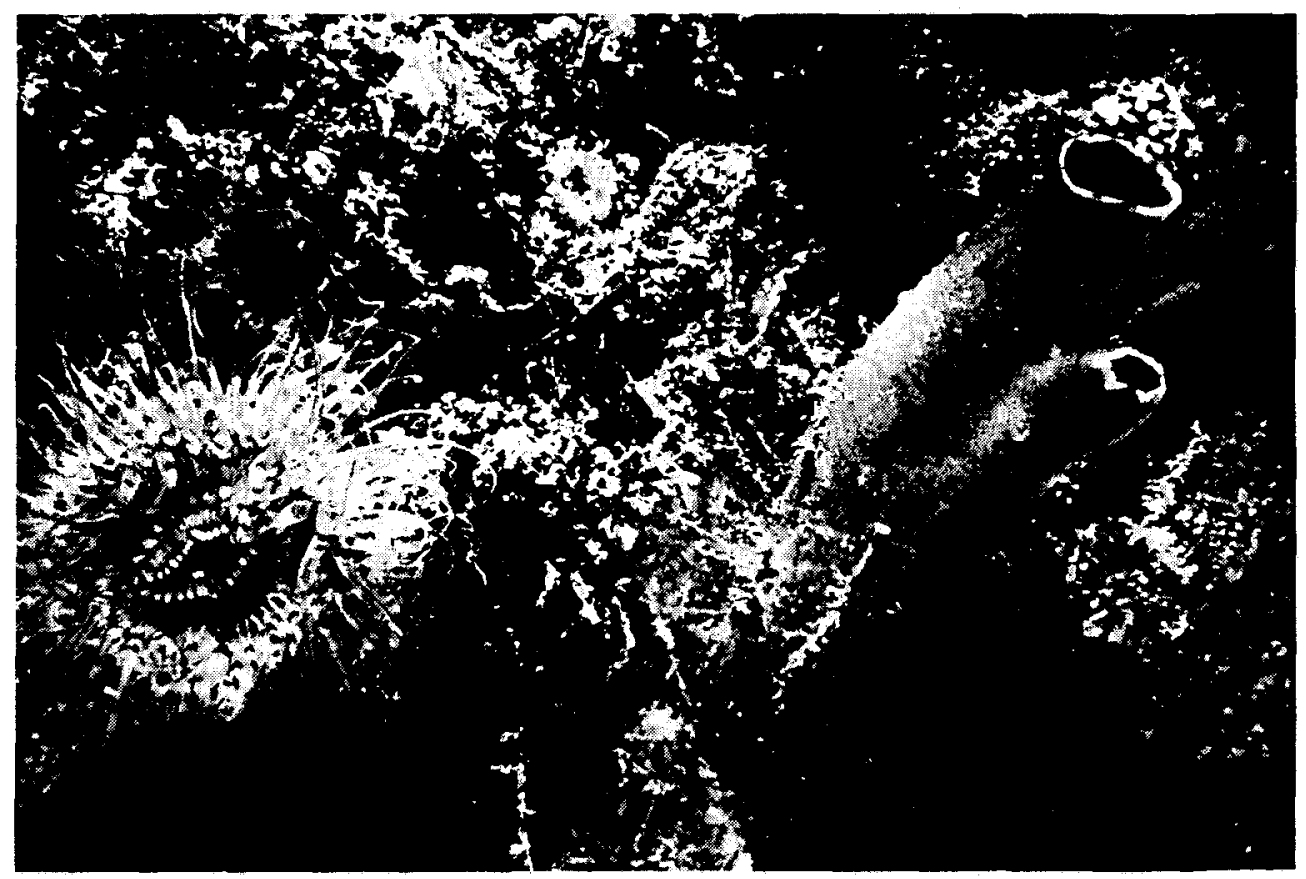

Fig. 10. Community $\mathrm{H}$ in the Südhafen, dominated by the anthozoan Sagartiogeton undatus and the tunicates Ascidiella aspersa, Ciona intestinalis and Botryllus schlosseri (photograph: Marcel Carpay) 
Community $\mathrm{F}$ is found between the islands Helgoland and Düne, at the location Nordreede (Ost and West), between 8.0 and $10.5 \mathrm{~m}$. A top layer is not developed in this community. The middle structural layer is dominated by the anthozoan Metridium senile and the polychaete Pomatoceros triqueter. The encrusting layer is mainly formed by the red alga Phymatolithon sp. The sediments belong to the types $I_{t} V$ and VI. The substrate is composed of red sandstone. The stations are sampled on nearly horizontal substrates

Table 8. Ordered diagram of the distribution of the vagile organisms over the different communities. The abundance is expressed as percentage presence over the stations of a community. Abbreviations: $\mathrm{Cr}$ - Crustacean, $\mathrm{Ch}$ - Chelicerate, Ech - Echinodermate, M - Mollusc, Pi - Pisces, P Polychaete

\begin{tabular}{|c|c|c|c|c|c|c|c|c|}
\hline Community: & $\mathrm{A}$ & B & C & $\mathrm{D}$ & $\mathrm{E}$ & $\mathbf{F}$ & G & $\mathrm{H}$ \\
\hline Archidoris pseudoargus (M) & 23 & 20 & 50 & 31 & 10 & 17 & 17 & 67 \\
\hline Ctenolabrus rupestris (Pi) & 31 & 40 & - & 60 & 10 & 33 & 83 & 67 \\
\hline Carcinus maenas $(\mathrm{Cr})$ & 15 & - & - & - & - & - & 17 & 100 \\
\hline Asterias rubens (Ech) & 85 & 100 & 50 & 100 & 100 & 83 & 83 & - \\
\hline Echinus esculentus (Ech) & 77 & - & - & 71 & 100 & 100 & 50 & - \\
\hline Rissoa parva (M) & 100 & 100 & 50 & 80 & 40 & 33 & 67 & - \\
\hline Gibbula cineraria $(\mathrm{M})$ & 46 & 20 & 50 & 29 & 60 & 100 & 17 & - \\
\hline Cancer pagurus $(\mathrm{Cr})$ & 23 & - & 50 & 60 & 70 & 67 & 33 & - \\
\hline Acanthodoris pilosa (M) & 8 & - & - & 3 & - & 33 & 17 & - \\
\hline Myoxocephalus scorpius (Pi) & 15 & - & 50 & 11 & 10 & 17 & 17 & - \\
\hline Nymphon rubrum (Ch) & 38 & 100 & - & 57 & 30 & 17 & 17 & - \\
\hline Caprella sp. (Cr) & 92 & 100 & 50 & 91 & 70 & 33 & - & - \\
\hline Macropodia rostrata $(\mathrm{Cr})$ & 8 & 40 & & - & 3 & - & - & - \\
\hline Hyas araneus $(\mathrm{Cr})$ & 15 & - & - & 23 & 20 & 50 & - & - \\
\hline Homarus gammarus $(\mathrm{Cr})$ & 8 & - & - & 3 & - & - & - & - \\
\hline Pholis gunnellus $\left(\mathrm{P}_{\mathrm{i}}\right)$ & 15 & 20 & - & 6 & - & 17 & - & - \\
\hline Enophrys bubalis (Pi) & 15 & - & - & 6 & 20 & 33 & - & - \\
\hline Amphipholis squamata (Ech) & 8 & - & - & 6 & - & 17 & - & - \\
\hline Ophiotrix fragilis (Ech) & 8 & - & - & 3 & - & - & - & - \\
\hline Lepidochitona cinerea (M) & 8 & - & - & - & - & 33 & - & - \\
\hline Polycera quadrilineata (M) & - & 40 & - & 9 & - & - & - & - \\
\hline Galathea strigosa $(\mathrm{Cr})$ & - & - & - & 20 & 30 & 33 & - & - \\
\hline Pagurus bernhardus ( $\mathrm{Cr}$ ) & - & - & - & 6 & 10 & 33 & - & - \\
\hline Pycnogonum littorale $(\mathrm{Ch})$ & - & - & - & 6 & - & - & - & _- \\
\hline Dendronotus frondosus (M) & - & - & - & 3 & - & - & - & - \\
\hline Janolus cristatus $(\mathrm{M})$ & - & - & - & 3 & - & - & - & - \\
\hline Coryphella pellucida (M) & - & - & - & 3 & - & - & - & - \\
\hline Lepidonotus squamatus $(\mathrm{P})$ & - & - & - & 3 & - & - & - & - \\
\hline Gadus morhua (Pi) & - & - & - & 3 & - & - & - & - \\
\hline Syngnathidae (Pi) & - & - & - & 3 & - & - & - & - \\
\hline Pleuronectes platessa ( $\mathrm{Pi})$ & - & - & - & - & 10 & - & - & - \\
\hline Zoarces viviparus (Pi) & - & - & - & - & - & 17 & - & - \\
\hline Crossaster papposus (Ech) & - & - & - & - & - & 17 & - & - \\
\hline
\end{tabular}


$\left(10-20^{\circ}\right)$ and vertical sides of boulders $\left(65^{\circ}\right)$. The amount of daylight varies between 6 and $11.5 \%$ of the surface intensity.

\section{Communities restricted to artificially constructed harbours}

The last main cluster ( $\mathrm{G}$ and $\mathrm{H}$ ) consists of two communities sampled in sheltered harbours in the south-east of Helgoland. Table 7 shows the ordered diagram for this cluster. Characteristic species of both communities are barnacles and the tunicate Botryllus schlosseri.

Community $\mathrm{G}$ is restricted to the Vorhafen. Most stations are sampled on vertical concrete quay-walls between 6.1 and $7.4 \mathrm{~m}$. One station is sampled at red sandstone on the bottom, with an angle of inclination of $5^{\circ}$. The community does not possess a top layer. The middle layer is dominated by tubicolous organisms and the tunicate Ascidiella aspersa. Characteristic species are the tunicate Clavelina lepadiformis, the red alga Trailliella intricata and the sponge Halichondria bowerbanki. The encrusting layer is dominated by the red algae Phymatolithon sp. and Hildenbrandia rubra. The amount of daylight received by the community varies between 6.5 and $10 \%$ of the surface intensity. Sediments on the bottom of the harbour belong to the types III, V and VI.

Community $\mathrm{H}$ is restricted to the sheltered Südhafen. The stations were sampled on vertical surfaces of iron poles, between 4.2 and $5.1 \mathrm{~m}$. A top layer is missing. The middle structural layer is dominated by tubicolous organisms, barnacles, the tunicate Botryllus schlosseri and the characteristic tunicates Ascidiella aspersa and Ciona intestinalis (Fig. 10). Other characteristic species are the ctenostome bryozoan Bowerbankia sp. and the anthozoan Sagartiogeton undatus. The sediment on the bottom of the harbour belongs to the fine types VI and VII.

Table 8 shows the distribution of the vagile organisms over the different communities. In the communities with the highest number of sessile organisms (the widespread algal dominated community $A$ and the heterogeneous community $D$, see Table 9), the highest number of vagile organisms were found. Communities which accomodate only small numbers of vagile organisms were the other algal dominated communities (B and $C$ ) and the communities restricted to the artificially constructed harbours ( $G$ and $H$ ).

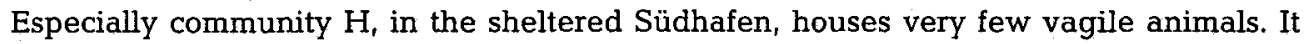
should be kept in mind that these vagile animals were only recorded within the quadrats of the stations. As these animals are vagile, only a faint idea of the real abundance of these organisms is given by these records.

\section{DISCUSSION}

The first division in the dendrogram (Fig. 4) divides the communities into two groups, viz.: communities in the natural environment and in an artificially constructed environment. The main difference between both is caused by the exposure to water movement and subsequently by differences in sedimentation.

In the natural environment the sublittoral hard substrate communities of Helgoland are determined by two major abiotic parameters and two modifying ones. The available amount of daylight restricts the depth of the photic zone. In this zone the communities are dominated by algae in the top and middle layer. As stated by Lüning \& Dring (1979), the turbidity of the waters and thus light conditions in the Helgoland region are extremely 
Table 9 . The contribution in $\%$ of different taxa to the community composition

\begin{tabular}{|l|rrrrrrrr|}
\hline Community: & A & B & C & D & E & F & G & H \\
\hline Top la ye r & & & & & & & & \\
Brown algae & 60.0 & 0.0 & 80.0 & 0.1 & 0.0 & 0.0 & 0.0 & 0.0 \\
Midd d e la y e r & & & & & & & & \\
Red algae & 28.6 & 24.8 & 4.2 & 1.9 & 0.0 & 1.0 & 22.2 & 1.8 \\
Brown algae & 14.7 & 2.0 & 12.4 & 0.5 & 0.0 & 0.2 & 0.0 & 0.1 \\
Green algae & 1.1 & 1.2 & 0.1 & 0.0 & 0.0 & 0.1 & 0.3 & 0.7 \\
Anthozoans & 3.2 & 4.3 & 0.3 & 23.8 & 20.9 & 48.2 & 2.0 & 1.9 \\
Tunicates & 1.5 & 5.2 & 0.2 & 0.9 & 0.0 & 0.3 & 22.4 & 68.1 \\
Bryozoans & 13.3 & 16.6 & 9.7 & 34.3 & 1.4 & 0.7 & 1.9 & 0.8 \\
Hydrozoans & 7.8 & 11.9 & 3.8 & 7.2 & 3.3 & 1.1 & 2.8 & 5.5 \\
Sponges & 1.7 & 1.5 & 3.3 & 4.5 & 0.5 & 0.1 & 10.6 & 4.6 \\
Bivalves & 0.1 & 0.1 & 0.3 & 0.2 & 0.0 & 0.0 & 0.0 & 0.0 \\
Crustaceans & 0.2 & 0.2 & 0.0 & 0.2 & 0.4 & 0.3 & 2.0 & 26.1 \\
Polychaetes & 0.5 & 0.0 & 0.0 & 0.9 & 46.2 & 6.6 & 0.9 & 0.1 \\
Tubicolous organisms & 13.3 & 30.9 & 0.3 & 15.9 & 2.4 & 0.9 & 11.0 & 12.7 \\
En c r u stin g la y e r & & & & & & & & \\
Red algae & 18.4 & 3.2 & 2.9 & 4.9 & 16.5 & 38.5 & 29.0 & 0.0 \\
Brown algae & 0.1 & 0.0 & 0.0 & 0.0 & 0.0 & 0.0 & 0.0 & 0.0 \\
Bryozoans & 3.1 & 12.1 & 0.8 & 7.3 & 7.7 & 2.3 & 0.0 & 0.2 \\
Bare substrate/sediment & 27.7 & 8.8 & 82.0 & 14.6 & 7.7 & 5.3 & 7.6 & 12.5 \\
Number of species & 93 & 72 & 25 & 105 & 49 & 51 & 53 & 33 \\
\hline
\end{tabular}

variable during different seasons. Algae dominated communities were found down to depths at which $10 \%$ of the surface light intensity was available (De Kluijver, 1989; De Kluijver et al., in prep.). As the exposure to water movement strongly varies with the topographic position in relation to the prevailing winds, this parameter cannot be considered as a regulator in the photic zone. The nature of the substrate is, however, a modifying parameter. Erosive substrates lead to poor development of the middle and encrusting structural layers.

The other communities in the natural environment are restricted to the aphotic zone. Encrusting algae may be present, but algae in the middle layer are of minor importance. Community E, dominated by the polychaete Pomatoceros triqueter, is probably the most widespread community in deeper waters in the Helgoland region (Klöckner, 1976; Anger, pers. comm.). Under more exposed conditions on the west side of Helgoland, the heterogenous community $\mathrm{D}$ is found. The three variants display different preferences regarding the angle of inclination and nature of the substrates. In the direction Nordreede, between Helgoland and Düne, community $E$ grades into community $F$. The distribution of the sediments indicates a decrease in current velocity, and the tidal currents seem to be forced around the west side of the collective base of the islands, instead of passing through the shallow passage between the islands. The main difference between communities $E$ and $F$ is the composition of the encrusting layer and the abundance of the polychaete Pomatoceros triqueter in the middle structural layer. 
The last two communities are located in the sheltered Vor- and Südhafen, an environment where sedimentation exceeds erosion. The community in the Vorhafen (G) also contains faunal and floral elements that are common outside the quay-walls in the natural environment. Some of the dominant and characteristic species of community $\mathrm{H}$ inside the extremely sheltered Südhafen (for instance the anthozoan Sagartiogeton undatus and the tunicates Botryllus schlosseri, Ciona intestinalis and Ascidiella aspersa) have been described as characteristic of the tideless salt water lake Grevelingen in the south-west Netherlands (De Kluijver, 1989). The tunicates, characteristic of sheltered environments, are able to create their own water movement, necessary for their food supply (Hiscock, 1983). Moreover, these species are able to survive at low levels of dissolved oxygen (Buizer, 1983). Suspension feeders (e.g. Metridium senile, Pomatoceros triqueter and Flustra foliacea), dominant in the exposed communities, are dependent on tidal currents for their food supply (Hiscock, 1983). This distribution is clearly seen in Table 9. A community dominated by Metridium senile has been found in the exposed mouth of the Oosterschelde estuary, south-west Netherlands (De Kluijver, 1989).

Although the communities are governed by the environmental parameters, many biotic interactions within the communities are also expected to be of importance. The first example of these biotic interactions are competitive interactions. Although definite proof is lacking, competitive interactions are likely to occur in the different structural layers of all communities (e.g. competition for space between Phymatolithon sp. and Hildenbrandia rubra, encrusting red algae and bryozoans; the overgrowth of Pomatoceros triqueter by bryozoans, especially in community $\mathrm{E}$ [see also Rubin, 1985]; and competition for food). More examples are given by Moore (1983). All these interactions, however, take place under conditions created by the environmental parameters. For example, an encrusting layer only develops under conditions with low potential sedimentation. This again depends on the water movement and input of suspended matter. Light intensity determines whether algae or bryozoans dominate this layer. When an encrusting layer develops under these conditions, it is irrelevant for the community structure which particular species occupies the substrates.

The second example of biotic interactions is the effect of vagile predators, including grazers, on community structure. One of the effects of predation is the reduced prey density. This may influence species richness and stability properties of the community (Hughes, 1980, 1985). The distribution of vagile organisms (Table 8), which includes several predators (such as the Nudibranchia Archidoris pseudoargus and Acanthodoris pilosa and the Echinodermata Asterias rubens and Echinus esculentus), does not indicate any relation to a particular community. Especially dominant predators (Asterias rubens,

Table 10. Comparison between the erosion values of the gypsum blocks and the sediment characteristics

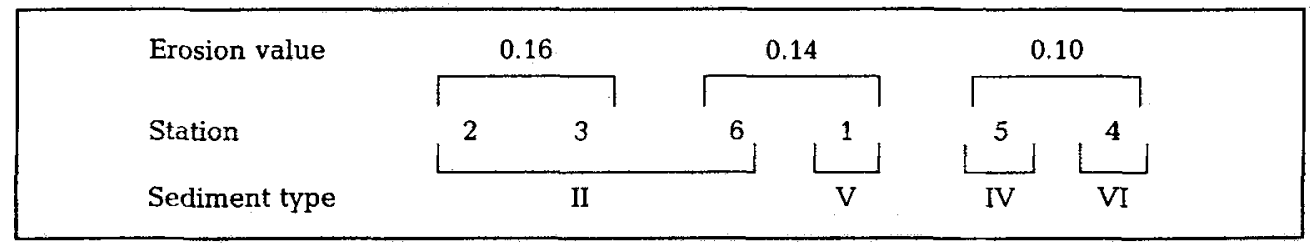


Echinus esculentus and the goldsinny Ctenolabrus rupestris) are distributed over a wide variety of communities. The occurrence of the same predators in the photic and aphotic zone indicates a wide dietary preference. In the sheltered Südhafen, community $H$, the low richness of sessile organisms (number of species $=33$ ) is probably not caused by a low predator intensity $(n=3)$. Comparing this community with other regions, the same community is found in the tideless lake Grevelingen in the south-west Netherlands (De Kluijver, 1989). In the Dutch situation, 22 vagile organisms were recorded within this community. The only species found at both localities is the shore crab Carcinus maenas, a real opportunist with a preference for the mussel Mytilus edulis (Hughes, 1980). However, Mytilus edulis is not found in community $\mathrm{H}$.

All these aspects indicate that instead of regulating the sublittoral communities, the vagile organisms in the studied localities depend themselves on the distribution of their prey organisms and on the environmental parameters.

\section{Evaluation of methods}

The quadrat sampling techniques and cluster analysis led to reproducible results. On the basis of the results of 1987, seven sublittoral communities were described. According to the completed data-set covering the stations sampled in 1988 and 1989, these communities did not change and were found to occur furthermore at the new stations (cf. Table 1). A new community in the Südhafen was sampled.

Similarly, the sediment characteristics did not change during these years. The use of these characteristics as an indicator of the tidal current velocity delivers the same results as those gained from the experiments using the gypsum blocks (Table 10). Both methods provide a relative scale which makes it possible to compare the total amount of water movement at the different stations. In this study, the sediment characteristics provide a more accurate scale, but for comparison of these communities with those in other environments, for instance in estuaries where sedimentation exceeds erosion, the use of gypsum blocks (or another method) is necessary.

The data analysis using the computer program TWINSPAN yielded the dendrogram of Figure 11. Communities E, F, G and $\mathrm{H}$ are not affected by the other cluster method. The

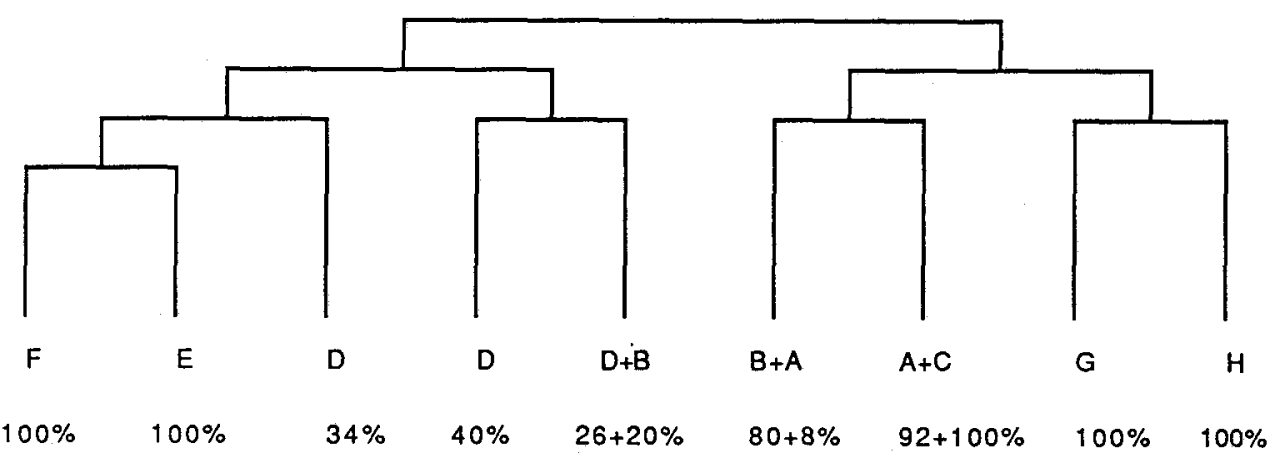

Fig. 11. Dendrogram resulting from cluster analysis using TWINSPAN. A comparison of the communities is made with CLUSTAN 
main difference in the photic zone is that TWINSPAN does not discriminate between communities $\mathrm{A}$ and $\mathrm{C}$ (both communities with a well developed canopy of Laminaria hyperborea). The only station of community. A without this top layer is added to the exposed community B. The heterogeneous community $D$ is divided into three groups as well. The variant dominated by Metridium senile clusters with communities $\mathrm{E}$ and F (both dominated by Metridium senile). Another division is made between the variant dominated by Flustra foliacea and the variant dominated by tubicolous organisms.

Despite all the advantages of TWINSPAN (Hill, 1979), the older CLUSTAN program is to be preferred, because the similarity between the stations is a fixed value, independent of new data input. This gives a more stable result when new data are added. Moreover, TWINSPAN does not give levels for new divisions. As similarity levels within different communities are not the same (e.g. compare community $D$ [similarity level 0.45 ] and community $\mathrm{H}$ [similarity level 0.69 ]), it is difficult to decide where to stop new divisions.

Acknowledgements. I wish to express my sincere thanks to the Biologische Anstalt Helgoland for the hospitality and the use of laboratory and diving facilities during my stays; to Gunther Tadday (Arbeitsgruppe Gastforschung) for helping to solve all kinds of practical problems; to Udo Schilling, Andreas and Thorsten Köhn, Dieter Klings, H. E. Lorenzen, Walter Röw and Hans Herman Lösche for their enthusiastic support during the sampling-trips with the "Diker" and "Aade"; to Dr Marcel Carpay, Dr Bea Steiff, Andreas Krüss M.Sc., Tatiana Eggert M.Sc., and Hans Reichenberger for their assistance during the diving work; Dr Marcel Carpay is also thanked for providing the photographs. I am most grateful to Udo Schilling and Juliane Schorn for their hospitality. Thanks are also due to Dr Rob van Soest, Dr Wallie de Weerdt for the identification of the sponges; to Dr Bert Buizer for checking the tunicates; to Dr J. C. den Hartog for checking some anthozoans; to Dr Jaap Kaandorp and Prof. Dr S. van der Spoel for their critical remarks; Jan Vermeulen is thanked for his practical help in the Netherlands; Prof. Dr J. H. Stock and Dr R. W. M. van Soest of the Institute of Taxonomic Zoology (Amsterdam) reviewed the first drafts of the manuscript. The "Wetterstation Helgoland" and the "Wasser- und Schiffahrtsamt", Tönning provided essential data for, respectively, the weather conditions and the water-levels. In 1987 this investigation was supported by the Koninklijke Nederlandse Akademie van Wetenschappen.

\section{LITERATURE CITED}

Anger, K., 1978. Development of a subtidal epifaunal community at the island of Helgoland. Helgoländer wiss. Meeresunters. 31,457-470.

Bloesch, J. \& Burns, N. M., 1980. A critical review of sedimentation trap technique. - Schweiz, Z. Hydrol. 42, 15-55.

Buizer, D. A. G., 1983. De Nederlandse zakpijpen (Manteldieren) en Mantelvisjes. Tunicata, Ascidiacea en Appendicularia. - Wet. Meded. K. ned natuurh. Veren. 158, 1-42.

Caspers, H., 1938. Die Bodenfauna der Helgoländer Tiefen Rinne. - Helgoländer wiss. Meeresunters. 2, 1-112.

Caspers, H., 1950. Die Lebensgemeinschaft der Helgoländer Austernbank. - Helgoländer wiss. Meeresunters. 3, 120-169.

Caspers, H., 1952. Der tierische Bewuchs an Helgoländer Seetonnen. - Helgoländer wiss. Meeresunters, 4, 138-160.

Gillandt, L., 1979a. Zur Ökologie der Polychaeten des Helgoländer Felslitorals. - Helgoländer wiss. Meeresunters, 32, 1-35.

Gillandt, L., 1979b. Zur Systematik, Biologie und Autökologie der Polychaeten des Helgoländer Felslitorals. - Mitt. hamb. zool. Mus. Inst. 76, 19-73. 
Gillbricht, M., 1987. Hydrographie, Nährstoffe und Phytoplankton bei Helgoland. - Jber. Biol. Anst. Helgoland, 1986, 29-32.

Gislen, T., 1930, Epibioses of the Gullmar Fjord II. (Kristinebergs Zoologiska Station 1877-1927). SkrSer. K. svenska Vetensk Akad. 1930 (4), 1-380.

Hagmeier, A., 1930. Die Besiedelung des Felsstrandes und der Klippen von Helgoland. Teil 1. Der Lebensraum. - Wiss. Meeresunters. (Helgoland) 15, 1-35.

Harms, J. \& Anger, K., 1983. Seasonal, annual, and spatial variation in the development of hard bottom communities. - Helgoländer Meeresunters. 36, 137-150.

Hill, M. O., 1979. TWINSPAN - A FORTRAN program for arranging multivariate data in an ordered two-way table by classification of individuals and attributes. Cornell Univ., Ithaca, N. Y., 90 pp.

Hiscock, K., 1983. Water movement. In: The ecology of the shallow sublittoral benthos. Ed. by R. Earl \& D. G. Erwin. Clarendon Press, Oxford, 58-96.

Hiscock, K. \& Hiscock, S., 1980. Sublittoral plant and animal communities in the area of Roaringwater Bay, South-West Ireland, - J. Sherkin Isl. 1, 7-48.

Hughes, R. N., 1980. Predation and community structure. In: The shore environment. Ed. by J. H. Price, D. E. G. Irvine \& W. F. Farnham. Acad. Press, London, 2, 699-728.

Hughes, R. N., 1985. Rocky shore communities: catalysts to understanding predation. In: The ecology of rocky coasts. Ed. by P. G. Moore \& R. Seed. Hodder \& Stoughton, London, 223-233.

Janke, K., 1986. Die Makrofauna und ihre Verteilung im Nordost-Felswatt von Helgoland. Helgoländer Meeresunters. 40, 1-55.

Kaandorp, J. A., 1986. Rocky substrate communities of the infralittoral fringe of the Boulonnais coast, NW France: a quantitative survey, - Mar. Biol. 92, 255-265.

Klöckner, K., 1976. Zur Ökologie von Pomatoceros triqueter (Linné 1758) (Serpulidae, Polychaeta). Diss. Univ. Tübingen, 168 pp.

Kluijver, M. J. de, 1989. Sublittoral hard substrate communities of the southern Delta area, SW Netherlands. - Bijdr. Dierk. 59, 141-158.

Könnecker, G. \& Keegan, B. F., 1983. Littoral and benthic investigations on the west coast of Ireland - XVII. The epibenthic animal associations of Kilkieran Bay. - Proc. R. Ir. Acad. 83B, 309-324.

Kornmann, P. \& Sahling, P.-H., 1977. Meeresalgen von Helgoland. - Helgoländer wiss. Meeresunters. 29, 1-289.

Korringa, P., 1968. Biological consequences of marine pollution with special reference to the North Sea fisheries. - Helgoländer wiss. Meeresunters. 17, 126-140.

Lüning, K., 1970. Tauchuntersuchungen zur Vertikalverteilung der sublitoralen Helgoländer Algenvegetation. - Helgoländer wiss. Meeresunters. 21, 271-291.

Lüning, K., 1985. Meeresbotanik. Thieme, Stuttgart, 375 pp.

Lüning, K. \& Dring, M. J., 1979. Continuous underwater light measurement near Helgoland (North Sea) and its significance for characteristic light limits in the sublittoral region. - Helgoländer wiss. Meeresunters. 32, 403-424.

Markham, J. W. \& Munda, I. M., 1980. Algal recolonization in the rocky eulittoral of Helgoland. Aquat. Bot. 9, 33-71.

Martens, P., 1978. Contribution to the hydrographical structure of the eastern German Bight. Helgoländer wiss. Meeresunters. 31, 414-424.

Moore, P. G., 1983. Biological interactions. In: The ecology of the shallow sublittoral benthos. Ed. by R. Earl \& D. G. Erwin. Clarendon Press, Oxford, 125-143.

Munda, I. M. \& Markham, J. W., 1982. Seasonal variations of vegetation patterns and biomass constituents in the rocky eulittoral of Helgoland. - Helgoländer Meeresunters. 35, 131-151.

Rubin, J. A., 1985. Mortality and avoidance of competitive overgrowth in encrusting Bryozoa. - Mar. Ecol. Prog. Ser. 23, 291-299.

Ruijter, W. P. M. de, Postma, L. \& Kok, J. M. de, 1987. Transport atlas of the southern North Sea. Rijkswaterstaat, The Hague, 33 pp.

Shin, P. K. S., 1982. Multiple discriminant analysis of macrobenthic infaunal assemblages. - J. exp. mar. Biol. Ecol. 59, 39-50.

Soest, R. W. M. van \& Weinberg, S., 1981. Preliminary quantitative assessment of the marine hard substrate communities of Roaringwater Bay. - J. Sherkin Isl. 1 (2), 10-26.

Sokal, R. R. \& Michener, C. D., 1958. A statistical method for evaluating systematic relationships. Kansas Univ. Sci. Bull, 38, 1409-1438. 
Straaten, L. M. J. U. van, 1973. De zee I: Water en waterbeweging. In: Algemene geologie. Ed. by A. J. Pannekoek. Tjeenk Willink, Groningen, 411-417.

Weinberg, S., 1978. The minimal area problem in invertebrate communities of Mediterranean rocky substrate. - Mar. Biol. 49, 33-40.

Weinberg, S., 1979. Mediterranean shallow-water Octocorallia. I. Ecology. Diss. Univ. of Amsterdam, $168 \mathrm{pp}$.

Wills, L. J., 1968. Palaeogeographical atlas. Blackie, London, 64 pp.

Wishart, D., 1978. CLUSTAN user manual. Program Library Unit, Edinburgh Univ., Edinburgh, $175 \mathrm{pp}$. 